\title{
Experimental and Computational Studies of the Molybdenum-Flanking Arene Interaction in Quadruply Bonded Dimolybdenum Complexes with Terphenyl Ligands
}

\author{
Mario Carrasco, ${ }^{[\mathrm{a}]}$ Irene Mendoza, ${ }^{[\mathrm{a}]}$ Eleuterio Álvarez, ${ }^{[\mathrm{a}]}$ Abdessamad Grirrane, ${ }^{[\mathrm{a}]}$ Celia Maya, ${ }^{[\mathrm{a}]}$ \\ Riccardo Peloso, ${ }^{[a]}$ Amor Rodríguez, ${ }^{[a]}$ Andrés Falceto, ${ }^{[b]}$ Santiago Álvarez, ${ }^{* b]}$ and Ernesto \\ Carmona* ${ }^{*}[\mathrm{a}]$
}

Abstract: To clarify the nature of the Mo- $\mathrm{C}_{\text {arene }}$ interaction in terphenyl complexes with quadruple Mo-Mo bonds, ether adducts of composition $\mathrm{Mo}_{2}\left(\mathrm{Ar}^{\prime}\right)(\mathrm{I})\left(\mathrm{O}_{2} \mathrm{CR}\right)_{2}\left(\mathrm{OEt}_{2}\right)$ have been prepared and characterized $\left(\mathrm{Ar}^{\prime}=\mathrm{Ar}^{\mathrm{Xyl} 2}, \mathrm{R}=\mathrm{Me}, \mathbf{4} \cdot \mathrm{OEt}_{2} ; \mathrm{Ar}^{\prime}\right.$ $=A r^{\text {Mes2 }}, \mathrm{R}=\mathrm{Me}, \mathbf{5} \cdot \mathrm{OEt}_{2} ; \mathrm{Ar}^{\prime}=\mathrm{Ar}^{\mathrm{Xyl} 2}, \mathrm{R}=\mathrm{CF}_{3}, \mathbf{6} \cdot \mathrm{OEt}_{2}$ ) and their reactivity toward different neutral Lewis bases investigated. $\mathrm{PMe}_{3}, \mathrm{P}(\mathrm{OMe})_{3}$ and $\mathrm{PPr}_{3}^{i}$ were chosen as $\mathrm{P}$ donors and the reactivity studies complemented with the use of the C-donors CNXyl and $\mathrm{CN}_{2} \mathrm{C}_{2} \mathrm{Me}_{4}$ (1,3,4,5tetramethylimidazol-2-ylidene). New compounds of general formula, $\mathrm{Mo}_{2}\left(\mathrm{Ar}^{\prime}\right)(\mathrm{I})\left(\mathrm{O}_{2} \mathrm{CR}\right)_{2}(\mathrm{~L}), \mathbf{4} \cdot \mathbf{L}-\mathbf{6} \cdot \mathbf{L}$ were obtained except for the imidazol-2-ylidene ligand that yielded a salt-like compound of composition $\left[\mathrm{Mo}_{2}\left(\mathrm{Ar}^{\mathrm{Xyl} / 2}\right)\left(\mathrm{O}_{2} \mathrm{CMe}\right)_{2}\left(\mathrm{CN}_{2} \mathrm{C}_{2} \mathrm{Me}_{4}\right)_{2}\right] \mathrm{l}, 7$.

The $\mathrm{Mo}-\mathrm{C}_{\text {arene }}$ interaction in these complexes has been analysed with the aid of X-ray data and computational studies. This interaction compensates the coordinative and electronic unsaturation of one of the Mo atoms in the above complexes but it seems to be weak in terms of sharing of electron density between the $\mathrm{Mo}$ and $\mathrm{C}_{\text {arene }}$ atoms and appears to have no appreciable effect in the length of the Mo-Mo, Mo-X and Mo- L bonds present in these molecules.

\section{Introduction}

Because of its fundamental importance in chemistry, the nature of the electronic interactions involved in chemical bonds of the Lewis type is a fascinating theme of research ${ }^{[1]} \mathrm{A}$ particularly appealing problem arises when the distance between the interacting atoms in a dative bond exceeds values expected for conventional covalent bonds. In these instances, the question arises as to whether there exists a true bond, that is, if there is sufficient a sharing of electrons to glue the atoms together. ${ }^{[2]}$ Among the many contingencies of this kind that have been disclosed in the literature ${ }^{[3]}$ the long $\mathrm{Cr}-\mathrm{C}_{\text {arene }}$ interactions present in the molecules of the quintuply metal-metal bonded $\mathrm{Ar}^{\prime} \mathrm{CrCrAr}$

[a] Dr. M. Carrasco, I. Mendoza, Dr. E. Álvarez, Dr. A. Grirrane, Dr. C. Maya, Dr. R. Peloso, Dr. A. Rodríguez, Prof. Dr. E. Carmona Instituto de Investigaciones Químicas

Departamento de Química Inorgánica Universidad de Sevilla-Consejo Superior de Investigaciones Científicas Avenida Américo Vespucio 49, 41092 Sevilla (Spain) Fax: (+34) 954460565

E-mail:guzman@us.es

\section{[b] A. Falceto, Prof. Dr. S. Álvarez} Departament de Química Inorgànica and Institut de Química Teòrica i Computacional, Universitat de Barcelona, Martí i Franquès 1-11, 08028 Barcelona (Spain) E-mail: santiago@qi.ub.es complexes reported by Power and co-workers ${ }^{[4]}\left(\mathrm{Ar}^{\prime}=\right.$ terphenyl ligand) constitute a most relevant example in the context of the work reported in this contribution. These dimers exhibit a transbent $\mathrm{C}_{\text {aryl }} \mathrm{CrCrC}_{\text {aryl }}$ planar core (Chart 1 , structure I) with a very short $\mathrm{Cr}-\mathrm{Cr}$ bond (ca. 1.81-1.83 $\AA$ ) and with $\mathrm{Cr}-\mathrm{C}_{\text {aryl }}$ distances of ca. $2.13 \AA$. However, each chromium atom features also a weaker $\mathrm{Cr}-\mathrm{C}_{\text {arene }}$ secondary interaction (at ca. $2.29 \AA$, consistent with the average distance found in the CSD for chromium-arene complexes, 2.24(6) A) with the ipso carbon of one of the aryl substituents of the terphenyl group bound to the other metal atom. Detailed structural and theoretical studies of this interaction ${ }^{[4,5]}$ revealed that it is much weaker than the sigma $\mathrm{Cr}-\mathrm{C}_{\text {aryl }}$ bond and causes only a small weakening of the $\mathrm{Cr} \equiv \mathrm{Er}$ bond. Most probably, this interaction partly compensates the electron deficiency of the twelve-electron chromium centres.

We have recently characterized some quadruply bonded terphenyl complexes of molybdenum and tungsten of composition $\mathrm{M}_{2}\left(\mathrm{Ar}^{\prime}\right)\left(\mathrm{O}_{2} \mathrm{CR}\right)_{3}$ and $\mathrm{M}_{2}\left(\mathrm{Ar}^{\prime}\right)_{2}\left(\mathrm{O}_{2} \mathrm{CR}\right)_{2}$ for different terphenyl $\left(\mathrm{Ar}^{\prime}\right)$ and carboxylate groups. ${ }^{[6]}$ Referring as representative examples to the molybdenum complexes, the mono-terphenyls exhibit structure of type II (Chart 1) in which one of the Mo atoms features a Mo- $\mathrm{C}_{\text {arene }}$ interaction at a distance of ca. $2.58 \AA$, slightly longer than the average molybdenum-arene distances found in the CSD, 2.38(8) $\AA$. In the bis-terphenyl derivatives (Chart 1, structure III) the Mo- $\mathrm{C}_{\text {arene }}$ separation increases significantly (ca. $2.78 \AA$ although it is still much shorter than the van der Waals radii sum of $4.22 \AA{ }^{[7]}$ In the two types of compounds there is a quadruple Mo-Mo bond of length ca. 2.10 $\AA$. In the absence of an extensive computational investigation we 
suggested ${ }^{[6 a]}$ that despite the weakness of the Mo- $\mathrm{C}_{\text {arene }}$ contacts $(2.58-2.80 \AA)$ relative to the Mo- $C_{\text {aryl }}$ bond $(2.16-2.19 \AA)$, the $\mathrm{Mo}-\mathrm{C}_{\text {arene }}$ interaction compensates in some degree the electronic unsaturation and offers at the same time steric protection to the unsaturated metal centre.

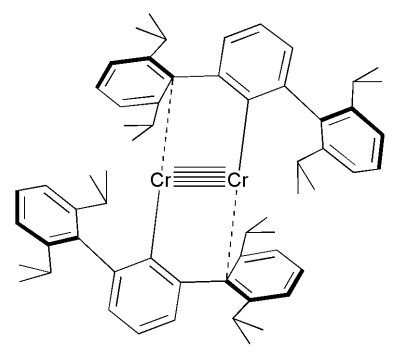

I

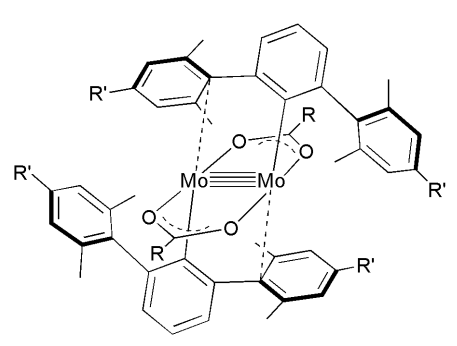

III

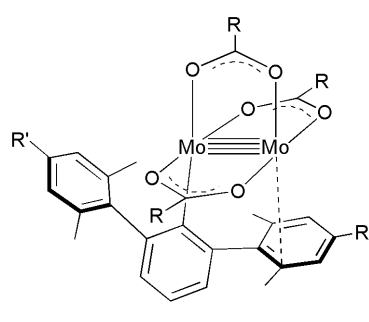

II

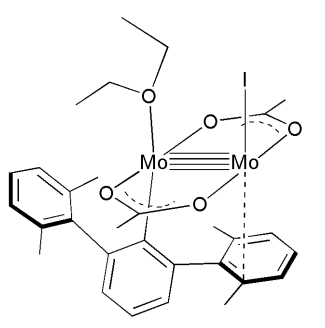

IV
Chart 1. Structural formulae of some multiply $M-M$ bonded dichromium and dimolybdenum complexes with terphenyl ligands.

To gain a deeper understanding on the nature of the Mo- $\mathrm{C}_{\text {arene }}$ interaction in these molecules we planned its comprehensive examination by means of experimental and theoretical methods. The work reported in this paper comprises the synthesis and structural characterization of new $\mathrm{Mo} \equiv \mathrm{Mo}$ complexes in which a $\left[\mathrm{Mo}_{2}\left(\mathrm{Ar}^{\prime}\right)\left(\mathrm{O}_{2} \mathrm{CMe}\right)_{2}\right]$ fragment is stabilized by the additional coordination of an iodide ligand and a neutral Lewis base $\left(\mathrm{Et}_{2} \mathrm{O}, \mathrm{PMe}_{3}, \mathrm{PPr}_{3}^{i}, \mathrm{P}(\mathrm{OMe})_{3}\right.$ and $\left.\mathrm{CNXyl}\right)$, or by two molecules of 1,3,4,5-tetramethylimidazol-2-ylidene, $\mathrm{CN}_{2} \mathrm{C}_{2} \mathrm{Me}_{4}$. As illustrated by the structure of a key synthetic precursor in this study, namely the ether adduct $\mathrm{Mo}_{2}\left(\mathrm{Ar}^{\mathrm{Xyl} / 2}\right)(\mathrm{I})\left(\mathrm{O}_{2} \mathrm{CMe}\right)_{2}\left(\mathrm{OEt}_{2}\right)$ 4. OEt $_{2}$ (structure IV in Chart 1), the four-coordinate molybdenum atom that would have a fourteen-electron count participates in a bonding interaction with the proximal flanking aryl ring that can increase the electron count to 16 . A computational study of this

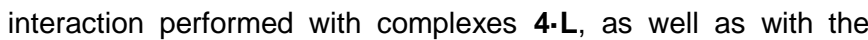
mono- and bis-terphenyl complexes $\mathrm{Mo}_{2}\left(\mathrm{Ar}^{\mathrm{Xyl} / 2}\right)\left(\mathrm{O}_{2} \mathrm{CMe}\right)_{3}$ and $\mathrm{Mo}_{2}\left(\mathrm{Ar}^{\mathrm{Xyl} / 2}\right)_{2}\left(\mathrm{O}_{2} \mathrm{CH}\right)_{2}$, respectively, is also reported, and compared with calculations on a model complex with an unsupported $\pi$ coordinated benzene ring, $\left[\mathrm{Mo}_{2}(\mathrm{H})\left(\mathrm{O}_{2} \mathrm{CMe}\right)_{3}\left(\mathrm{C}_{6} \mathrm{H}_{6}\right)\right]$.

\section{Results and Discussion}

\section{Synthesis and solution structure of new complexes 4-L-7}

In collaboration with the group of Power, we reported recently the synthesis and characterization of a variety of terphenyl complexes of the $\mathrm{Mo} \equiv$ Mo core that comprised monoterphenyl derivatives with composition $\mathrm{Mo}_{2}\left(\mathrm{Ar}^{\prime}\right)\left(\mathrm{O}_{2} \mathrm{CR}\right)_{3}$, for different terphenyl (Ar') and carboxylate groups. ${ }^{[6]}$ With some exceptions, these compounds did not undergo reaction with a second equivalent of $\mathrm{LiAr}$ ' to yield the targeted $\mathrm{Mo}_{2}\left(\mathrm{Ar}^{\prime}\right)_{2}\left(\mathrm{O}_{2} \mathrm{CR}\right)_{2}$ complexes.

At variance with this observation, $\mathrm{Et}_{2} \mathrm{O}$ solutions of the complex $\mathrm{Mo}_{2}\left(\mathrm{Ar}^{\prime}\right)\left(\mathrm{O}_{2} \mathrm{CR}\right)_{3}$, where $\mathrm{Ar}^{\prime}=\mathrm{Ar}^{\mathrm{Xyl2}}$ and $\mathrm{R}=\mathrm{Me}$ (complex 1), reacted cleanly and smoothly (20 $\stackrel{\circ}{ } \mathrm{C}$, overnight) with $\mathrm{Mgl}_{2}$ dissolved also in $\mathrm{Et}_{2} \mathrm{O}$ (Scheme 1) to afford $\mathrm{Mo}_{2}\left(\mathrm{Ar}^{\mathrm{Xyl}}\right)(\mathrm{I})\left(\mathrm{O}_{2} \mathrm{CMe}\right)_{2}\left(\mathrm{OEt}_{2}\right)$, 4. OEt 2 , in fair isolated yields (ca. $55 \%$ ). The substitution of the acetate group of 1 , which is trans with respect to the $\sigma$-bonded Ar' ligand, by iodide and a molecule of $\mathrm{Et}_{2} \mathrm{O}$ was accompanied by an attractive colour change from dark red to blue-violet. The new compound is soluble in common organic solvents (e.g. $\mathrm{Et}_{2} \mathrm{O}, \mathrm{C}_{6} \mathrm{H}_{6}$, or $\mathrm{C}_{6} \mathrm{H}_{5} \mathrm{Me}$ ) and is very reactive toward oxygen and water, both in solution and in the solid state. As represented also in Scheme 1, the related compounds $\mathrm{Mo}_{2}\left(\mathrm{Ar}^{\mathrm{Mes} 2}\right)\left(\mathrm{O}_{2} \mathrm{CMe}\right)_{3}, \quad$ 2, and $\mathrm{Mo}_{2}\left(\mathrm{Ar}^{\mathrm{Xyl} / 2}\right)\left(\mathrm{O}_{2} \mathrm{CF}_{3}\right)_{3}$, 3, reacted similarly with $\mathrm{Mgl}_{2}$ to furnish analogous $\mathrm{Et}_{2} \mathrm{O}$ adducts, namely 5. $\mathrm{OEt}_{2}$ and 6. $\mathrm{OEt}_{2}$. Along with $\mathbf{4} \cdot \mathrm{OEt}_{2}$, the former was isolated and characterized by spectroscopy and X-ray crystallography. The related trifluoroacetate $\mathbf{6} \cdot \mathbf{O E t}_{2}$ was simply used in situ for further reactivity studies.

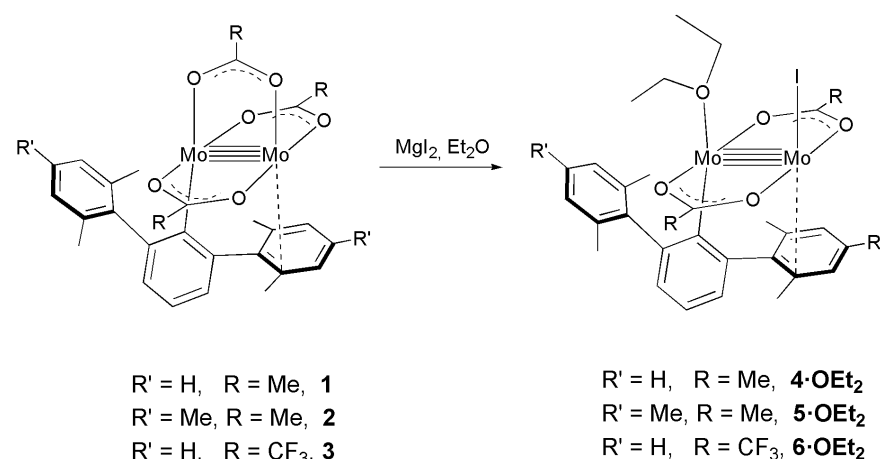

Scheme 1. Synthesis of ether adducts of monoterphenyl iodide complexes.

NMR data $\left({ }^{1} \mathrm{H}\right.$ and $\left.{ }^{13} \mathrm{C}\left\{{ }^{1} \mathrm{H}\right\}\right)$ for new compounds are fully in accordance with the proposed formulation (see Supporting Information, SI, for details). Taking complex $\mathbf{4} \cdot \mathbf{O E t}_{2}$ as an illustrative example, the room temperature ${ }^{1} \mathrm{H}$ NMR spectrum contains somewhat broad resonances due, at least in part, to facile dissociation of the $\mathrm{Et}_{2} \mathrm{O}$ molecule (fast exchange between free and coordinated $\mathrm{Et}_{2} \mathrm{O}$ was observed in the presence of added $\left.\mathrm{Et}_{2} \mathrm{O}\right)$. But in addition, the proximal and distal Xyl flanking rings ( $\delta 2.09$ and 2.23) undergo exchange that becomes fast on the NMR time scale at temperatures above $45^{\circ} \mathrm{C}$. This exchange is somewhat more facile than in the parent complex $\mathbf{1}$ and could be explained similarly ${ }^{[6 a]}$ assuming a 1,2-terphenyl shift from one Mo atom to the other through a $\mathrm{Mo}_{2}\left(\mu-\mathrm{Ar}^{\prime}\right)$ structure facilitated by dissociation of the molecule of $\mathrm{Et}_{2} \mathrm{O}$. The lability of the $\mathrm{Et}_{2} \mathrm{O}$ ligand could additionally allow for a similar iodide shift, as suggested by the computational studies to be discussed in a following section.

New complexes related to $4 \cdot \mathrm{OEt}_{2}, \mathbf{5} \cdot \mathrm{OEt}_{2}$, and $\mathbf{6} \cdot \mathrm{OEt}_{2}$ formed upon reactions of these molecules with different Lewis bases (Scheme 2). Thus, treatment of $\mathbf{4} \cdot \mathbf{O E t}_{2}$ with the phosphorus 
donors $\mathrm{PMe}_{3}, \mathrm{P}(\mathrm{OMe})_{3}$, and $\mathrm{PPr}_{3}^{i}$ yielded the expected adducts 4. $\mathrm{PMe}_{3}$ (deep-blue), 4.P(OMe) ${ }_{3}$ (purple), and 4- $\mathrm{PPr}_{3}{ }_{3}$ (violet). For complexes $5 \cdot \mathrm{OEt}_{2}$ and $\mathbf{6} \cdot \mathrm{OEt}_{2}$ only the reactions with $\mathrm{PMe}_{3}$ were carried out to generate $\mathbf{5} \cdot \mathrm{PMe}_{3}$ and $\mathbf{6} \cdot \mathrm{PMe}_{3}$, respectively, both with deep-blue colour. As shown in Scheme 2 the substitution of $\mathrm{Et}_{2} \mathrm{O}$ by the $\mathrm{P}$-donor ligands occurred with a discernible stereochemical change that placed the iodide ligand in the coordination position trans with respect to the Ar' group while the phosphorus ligand bonded to the lower coordinated Mo atom that participates in the secondary $\mathrm{Mo}-\mathrm{C}_{\text {arene }}$ interaction. A theoretical justification for this rearrangement will be provided in a later section. In the meantime, the different site of coordination of the neutral Lewis base may be discerned from the observation of a doublet ${ }^{13} \mathrm{C}\left\{{ }^{1} \mathrm{H}\right\}$ Mo- $C_{\text {aryl }}$ resonance at $173.2 \mathrm{ppm}$ that exhibits a reduced ${ }^{13} \mathrm{C}-{ }^{31} \mathrm{P}$ coupling of $9 \mathrm{~Hz}$. This value is significantly smaller than expected for a two-bond trans- $\mathrm{C}_{\text {aryl}}-\mathrm{Mo}-\mathrm{P}$ coupling ${ }^{[8]}$ and points instead to a trans-bent $\mathrm{C}_{\text {aryl }}-\mathrm{Mo}-\mathrm{Mo}-\mathrm{P}$ ligand arrangement, subsequently confirmed by $\mathrm{X}$-ray crystallography.
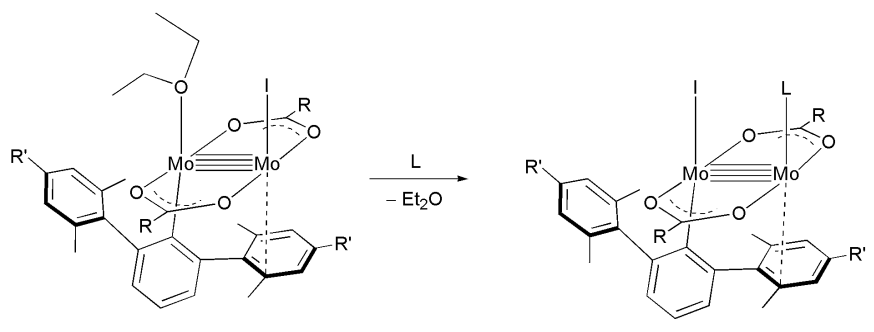

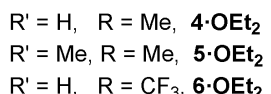

$\mathrm{R}^{\prime}=\mathrm{H}, \quad \mathrm{R}=\mathrm{Me}, \mathbf{4} \cdot \mathrm{L}$

$\mathrm{R}^{\prime}=\mathrm{Me}, \mathrm{R}=\mathrm{Me}, \mathbf{5} \cdot \mathrm{L}$

$\mathrm{R}^{\prime}=\mathrm{H}, \quad \mathrm{R}=\mathrm{CF}_{3}, \mathbf{6} \cdot \mathrm{L}$

Scheme 2. Substitution reactions in complexes $4 \cdot \mathrm{OEt}_{2}, \mathbf{5} \cdot \mathrm{OEt}_{2}$ and $\mathbf{6} \cdot \mathrm{OEt}_{2}$ by neutral Lewis bases. See text for the nature of $L$.

The ${ }^{1} \mathrm{H}$ and ${ }^{31} \mathrm{P}\left\{{ }^{1} \mathrm{H}\right\}$ NMR spectra of 4. $\mathrm{PMe}_{3}$ (see SI) show no indications either for $\mathrm{PMe}_{3}$ dissociation or for exchange of the flanking aryl rings of the terphenyl ligand, $\mathrm{Ar}^{\mathrm{Xyl} 2}$. Nonetheless, the xylyl exchange becomes apparent with the aid of NOESY experiments. Benzene solutions of the related $4 \cdot \mathrm{P}(\mathrm{OMe})_{3}$ and 4. $\mathrm{PPr}_{3}{ }_{3}$ adducts display similar properties and give rise, for instance, to a Mo- $C_{\text {aryl }}{ }^{13} \mathrm{C}\left\{{ }^{1} \mathrm{H}\right\}$ resonance that appears as a doublet around $172 \mathrm{ppm}\left({ }^{3} \mathrm{~J}_{\mathrm{C}, \mathrm{P}}\right.$ ca. 9-10 Hz). However, ether solvents like $\mathrm{Et}_{2} \mathrm{O}$ and $\mathrm{THF}$ induced ligand dissociation and substitution by the ether, to restore the starting complex $4 . \mathbf{O E t}_{2}$ (or the related 4.THF that was not investigated any further). For example, in the ${ }^{31} \mathrm{P}\left\{{ }^{1} \mathrm{H}\right\}$ NMR spectrum of a concentrated solution of $4 \cdot \mathrm{PPr}_{3}$ in THF- $d_{8}$ signals corresponding to coordinated (47.5 $\mathrm{ppm}$ ) and free (19.4 ppm) phosphine were recorded. Under these conditions the Mo- $C_{\text {aryl }}$ resonance appears in the ${ }^{13} \mathrm{C}\left\{{ }^{1} \mathrm{H}\right\}$ NMR spectrum as a singlet. UV-Vis spectroscopic data that will be discussed later provided additional evidence for this substitution process, that under sufficiently high THF : $4 \cdot \mathrm{PPr}_{3}{ }_{3}$ molar ratios (ca. $10^{-4} \mathrm{M}$ solutions) yields $\mathbf{4} \cdot \mathbf{T H F}$ and free $\mathrm{PPr}^{i}$. Indeed the facile dissociation of the P-donor ligands of the above compounds finds precedent in the work of Andersen and co-workers on other phosphine containing organometallic complexes of the quadruple Mo-Mo bond. ${ }^{[9]}$

The lability of the coordinated molecule of $\mathrm{Et}_{2} \mathrm{O}$ in the adducts 4. $\mathrm{OEt}_{2}-\mathbf{6} \cdot \mathrm{OEt}_{2}$ made us wonder if $\mathrm{CO}$ coordination to their $\mathrm{Mo} \equiv$ Mo central unit could be achieved. However, no observable reaction took place between $4 . \mathrm{OEt}_{2}$ and $\mathrm{CO}$ (1 bar) either at room temperature or in boiling THF. Since $\mathrm{CO}$ is poor a $\sigma$-donor but excellent a $\pi$-acceptor ligand, the lack of reactivity could be attributed to full involvement of the filled $d \pi$ orbitals of the molybdenum atoms into Mo-Mo multiple bonding. In fact, the almost invariable Mo-Mo distance of ca. $2.10 \AA$ found in these and related $^{[6]}$ complexes is characteristic of typical, strong quadruple bonds. ${ }^{[10]}$ To confirm this assumption, complexes 4. $\mathrm{OEt}_{2}-\mathbf{6} \cdot \mathrm{OEt}_{2}$ were reacted with CNXyl. Isocyanides ${ }^{[11]}$ are better $\sigma$-donors and poorer $\pi$-acceptors than carbon monoxide. Arylisocyanides are more efficient $\pi$-acids than alkylisocyanides but behave essentially as $\sigma$-donors when bound to high-valent metals or to poor $\pi$-donor metal units. ${ }^{[12,13]}$ As depicted in Scheme $2(\mathrm{~L}=\mathrm{CNXyl})$, treatment of solutions of the above complexes with 1 equiv of $\mathrm{CNXyl}$ dissolved also in $\mathrm{Et}_{2} \mathrm{O}$, led to an immediate colour change to green and permitted the isolation of the corresponding adducts 4. CNXyl-6. CNXyl as very air sensitive crystalline solids.

Spectroscopic data for the new compounds (see SI) are in agreement with the proposed formulation. An informative hallmark is an IR absorption in the proximity of $2140 \mathrm{~cm}^{-1}$ due to $\bar{v}(C \equiv N)$ of the coordinated isocyanide. This band is shifted by ca. $25 \mathrm{~cm}^{-1}$ to higher wavenumbers relative to free isocyanide (2114 $\mathrm{cm}^{-1}$ ). Since the isocyanide donates electron density from a molecular orbital localized on carbon that has some antibonding character (alike the HOMO of $\mathrm{CO}$ ), $\sigma$-donation results in a strengthening of the $\mathrm{C}-\mathrm{N}$ bond and a concomitant increase of $\bar{v}(\mathrm{C} \equiv \mathrm{N}) \cdot{ }^{[11-13]}$ Thus, the positive shift of ca. $25 \mathrm{~cm}^{-1}$ observed for complexes 4.CNXyl-6.CNXyl indicates that the Mo-CNAr bonding interaction is mostly (or exclusively) of the sigma $\mathrm{Mo} \leftarrow$ CNAr type ${ }^{[13]}$ and confirms that the Mo $\equiv$ Mo core of these complexes behaves as a poor $\pi$-donor toward $\pi$-acid ligands.
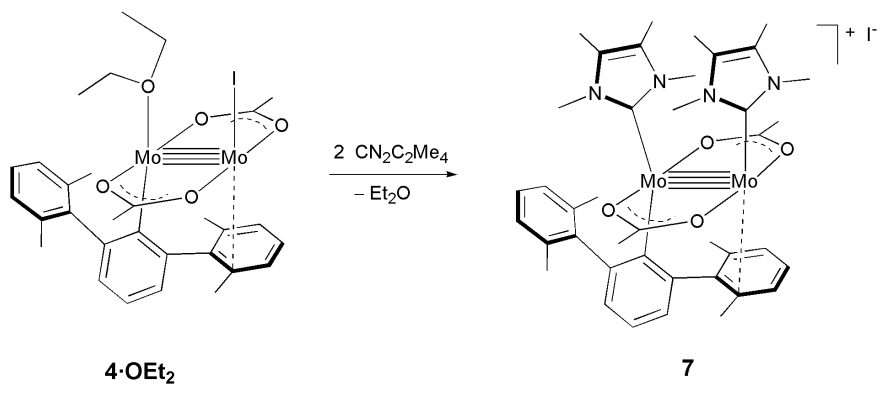

Scheme 3. Formation of the salt-like compound $\mathbf{7}$ by reaction of $\mathbf{4} \cdot \mathbf{O E t}_{2}$ with $\mathrm{CN}_{2} \mathrm{C}_{2} \mathrm{Me}_{4}$.

To complete these synthetic studies we explored the reactivity of complex $4 . \mathrm{OEt}_{2}$ toward the $\mathrm{N}$-heterocyclic carbene $\mathrm{CN}_{2} \mathrm{C}_{2} \mathrm{Me}_{4}$. In marked contrast with the reactions already discussed, the resulting product, $\mathbf{7}$, was insoluble in THF and precipitated out of the reaction mixture (Scheme 3). Characterization studies revealed that complex 7 contains two molecules of $\mathrm{CN}_{2} \mathrm{C}_{2} \mathrm{Me}_{4}$ which are bound to the two molybdenum atoms and therefore that the imidazol-2-ylidine ligand displaced both the $\mathrm{Et}_{2} \mathrm{O}$ and $\mathrm{I}^{-}$groups of $4 . \mathrm{OEt}_{2}$, to yield the cationic complex 
$\left[\mathrm{Mo}_{2}\left(\mathrm{Ar}^{\mathrm{Xyl}}\right)\left(\mathrm{O}_{2} \mathrm{CMe}\right)_{2}\left(\mathrm{CN}_{2} \mathrm{C}_{2} \mathrm{Me}_{4}\right)_{2}\right]^{+}$, isolated as the iodide salt. It is worth mentioning in this regard that compound 7 was the only detectable product of the reaction regardless of the $4 \cdot \mathbf{O E t}_{2}: 2$ $\left(\mathrm{CN}_{2} \mathrm{C}_{2} \mathrm{Me}_{4}\right)$ molar ratio utilized. It was isolated as magenta crystals from its solutions in $\mathrm{CH}_{2} \mathrm{Cl}_{2}: \mathrm{C}_{6} \mathrm{H}_{5} \mathrm{Me}$ solvent mixtures. The aliphatic region of the ${ }^{1} \mathrm{H}$ NMR spectrum of 7 recorded at room temperature in $\mathrm{CD}_{2} \mathrm{Cl}_{2}$ is simple and consists of four singlets at $1.90,2.09,2.52$ and $2.80 \mathrm{ppm}$, with relative intensities attributable to $12 \mathrm{H}, 12 \mathrm{H}, 12 \mathrm{H}$ and $6 \mathrm{H}$, respectively. Clearly, at this temperature the two flanking xylyl substituents of the terphenyl ligand undergo fast exchange in the NMR time scale. By similarity with related complexes, ${ }^{[6 a]}$ this dynamic behavior could be due to a fast 1,2-terphenyl shift from one Mo atom to the other through a Mo $\left(\mu-\mathrm{Ar}^{\prime}\right) \mathrm{Mo}$ intermediate or transition state. We have been able to computationally locate a Mo( $\mu$-Ar')Mo transition state for the 1,2-terphenyl shift from one Mo atom to the other (Figure 1) in $\left[\mathrm{Mo}_{2}\left(\mathrm{Ar}^{\mathrm{Xyl} / 2}\right)\left(\mathrm{O}_{2} \mathrm{CMe}\right)_{2}\left(\mathrm{CN}_{2} \mathrm{C}_{2} \mathrm{Me}_{4}\right)_{2}\right]^{+}$, with a relative free energy of $12.45 \mathrm{kcal} / \mathrm{mol}$, consistent with the dynamic behavior observed in the ${ }^{1} \mathrm{H}-\mathrm{NMR}$ spectrum at room temperature. It must be noted that the incipient interaction between the ipso atom of the non-bonded aryl group and a Mo atom in the axial region (at a distance of $3.37 \AA$ in the calculated structure, $3.36 \AA$ in the experimental structure), is shortened as the central phenyl ring shifts to a bridging position in the transition state, ending up in an $\eta^{1}$ coordination through an ortho atom.

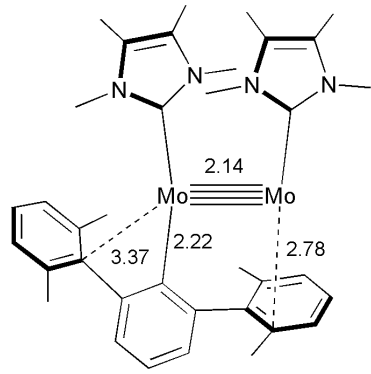

Ground State

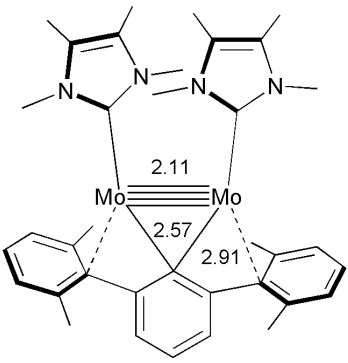

Transition State
Figure 1. Optimized ground state of $\left[\mathrm{Mo}_{2}\left(\mathrm{Ar}^{\mathrm{Xy} l_{2}}\right)\left(\mathrm{O}_{2} \mathrm{CMe}\right)_{2}\left(\mathrm{CN}_{2} \mathrm{C}_{2} \mathrm{Me}_{4}\right)_{2}\right]^{+}$and transition state for the 1,2-aryl shift. The acetate groups are omitted for clarity. Some relevant distances are given in $\AA$.

As briefly noted earlier, the reactions that led to complexes of type 4-7 were accompanied by remarkable colour changes. We conclude this section with a succinct discussion of the UV-Vis spectra of these compounds. Figure 2a compares the spectrum of the parent complex 1 with those of the $\mathbf{4} \cdot \mathbf{L}$ adducts, where $\mathrm{L}=$ $\mathrm{Et}_{2} \mathrm{O}, \mathrm{PMe}_{3}$ and $\mathrm{CNXyl}$. Figure $2 \mathrm{~b}$ highlights the similar optical properties of $4 \cdot \mathrm{PMe}_{3}, \mathbf{4} \cdot \mathrm{P}(\mathrm{OMe})_{3}$, and $4 \cdot \mathrm{PPr}_{3}{ }_{3}$. All compounds exhibit a strong absorption in the range 530-630 nm (ca. $18870-18020 \mathrm{~cm}^{-1}$ ) with $\varepsilon_{\max }$ varying between 1100 (1) and 1760 (4. CNXyl) $\mathrm{M}^{-1} \mathrm{~cm}^{-1}$. In addition, a less intense band $\left(\varepsilon_{\max }\right.$ ca. 540 $\mathrm{M}^{-1} \mathrm{~cm}^{-1}$ ) can be discerned in the proximity of $440 \mathrm{~cm}^{-1}$. By analogy with other terphenyl complexes of the $\left(\mathrm{Mo}_{2}\right)^{4+}$ unit, ${ }^{[6]}$ these bands can be attributed to $\delta^{2} \rightarrow \delta \delta^{*}$ transitions. The above data compare well with previous findings by $\operatorname{Cotton}^{[14]}$ and Gray ${ }^{[15]}$ in the complexes $\mathrm{Mo}_{2} \mathrm{X}_{4}\left(\mathrm{PMe}_{3}\right)_{4}$, where $\lambda_{\max }$ changes between $550(X=F)$ to $633 \mathrm{~nm}(X=I)$. These variations were attributed to changes in the energy of the LUMO $\left(\delta^{*}\right)$, rather than in the HOMO $(\delta) .{ }^{[14]}$
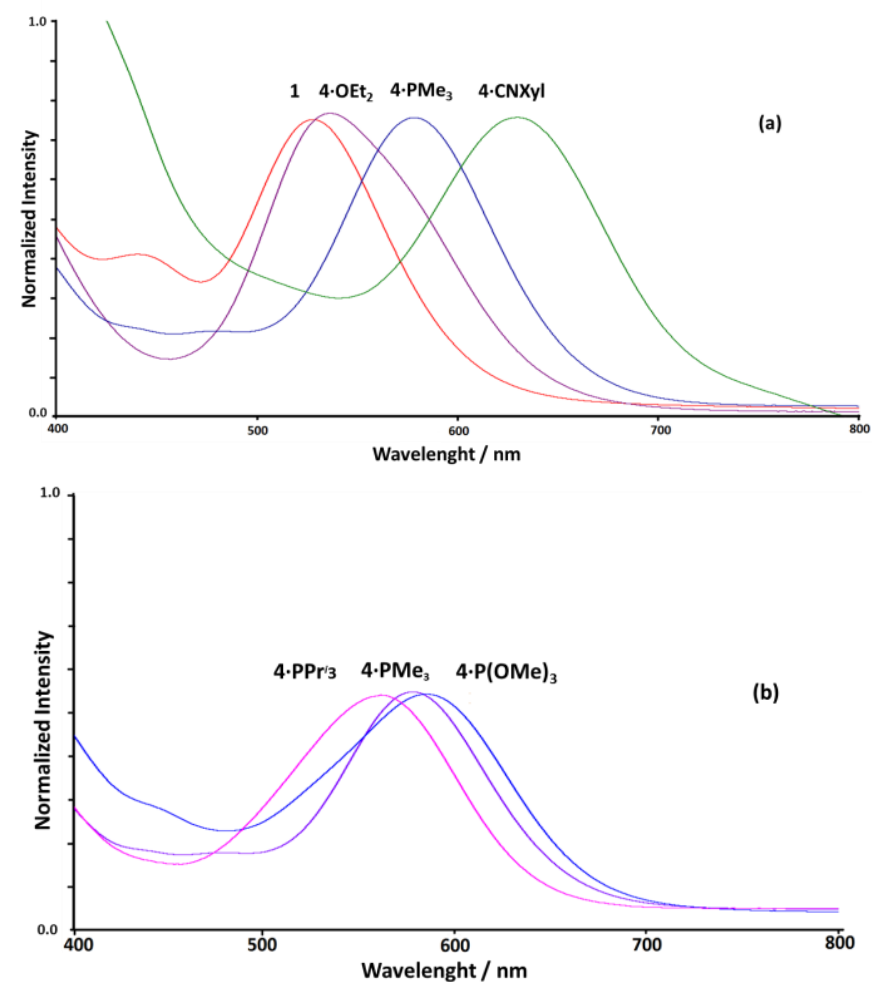

Figure 2. UV-Vis absorption spectra of compounds $\mathbf{1}, \mathbf{4} \cdot \mathbf{O E t} \mathrm{E}_{2}, \mathbf{4} \cdot \mathrm{PMe}_{3}$ and 4.CNXyl (a) and of the three complexes 4.L with P-donor ligands (b) in benzene solutions (ca. $\left.10^{-4} \mathrm{M}\right)$.

At this stage, it is worth recalling that UV-Vis spectroscopy provides unequivocal evidence for partial dissociation of the $\mathrm{P}$ donor ligands of $\mathbf{4} \cdot \mathbf{P}(\mathrm{OMe})_{3}$ and $\mathbf{4} \cdot \mathrm{PPr}_{3}{ }_{3}$ when dissolved in $\mathrm{Et}_{2} \mathrm{O}$ or THF. As represented in Figure $3 \mathrm{a}, \lambda_{\max }$ of $4 \cdot \mathrm{PPr}^{i}{ }_{3}$ shifts from 560 to $540 \mathrm{~nm}$ upon changing the solvent from $\mathrm{C}_{6} \mathrm{H}_{6}$ to $\mathrm{THF}$, the latter spectrum being identical to that of $4 . \mathrm{OEt}_{2}$ dissolved in THF. Similar variations were recorded for $\mathbf{4} \cdot \mathbf{P}(\mathrm{OMe})_{3}$ (Figure $\left.3 b\right)$.

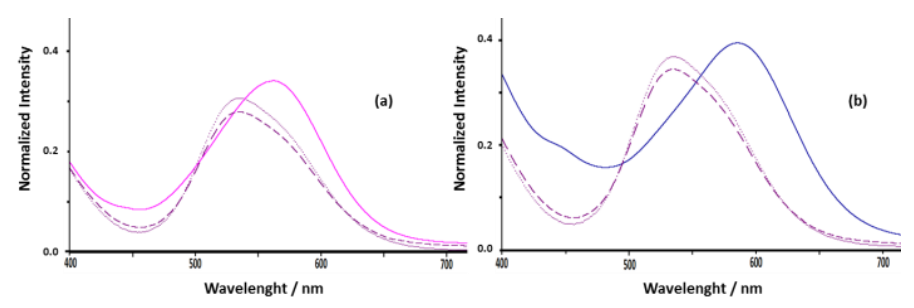

Figure 3. Absorption spectra of $4 \cdot \mathrm{PPr}_{3}^{i}(\mathbf{a})$ and $\mathbf{4} \cdot \mathbf{P}(\mathrm{OMe})_{3}(\mathbf{b})$ in benzene $(-)$ and THF (---) solutions (ca. $\left.10^{-4} \mathrm{M}^{-1}\right)$. In the two figures the spectrum of complex 4.0Et ${ }_{2}$ dissolved in THF $\left(\right.$ ca. $\left.10^{-4} \mathrm{M}\right)$ is represented with dotted lines $(\cdots)$. 
Table 1. Selected Bond Lengths [Å] and Angles [deg] for Complexes $\mathrm{Mo}_{2}\left(\mathrm{Ar}^{\mathrm{xy} / 2}\right)\left(\mathrm{O}_{2} \mathrm{CMe}\right)_{3},(\mathbf{1}), \mathrm{Mo}_{2}\left(\mathrm{Ar}^{\mathrm{Xy} / 2}\right)_{2}\left(\mathrm{O}_{2} \mathrm{CH}\right)_{2}, \mathbf{4} \cdot \mathrm{L}\left(\mathrm{L}=\mathrm{Et}_{2} \mathrm{O}, \mathrm{PMe} \mathrm{e}_{3}, \mathrm{P}\left(\mathrm{OMe}_{3}, \mathrm{PPr}{ }_{3}^{i}, \mathrm{CNXyl}\right)\right.$ and $\left[\mathrm{Mo}_{2}\left(\mathrm{Ar}^{\mathrm{Xyl}}\right)\left(\mathrm{O}_{2} \mathrm{Me}\right)_{2}\left(\mathrm{CN}_{2} \mathrm{C}_{2} \mathrm{Me}_{4}\right)_{2}\right] \mathrm{l}, 7$.

\begin{tabular}{|c|c|c|c|c|c|c|c|c|}
\hline Parameter & $1^{[a]}$ & $\mathrm{Mo}_{2}\left(\mathrm{Ar}^{\mathrm{Xyl}{ }_{2}}\right)_{2}\left(\mathrm{O}_{2} \mathrm{CH}\right)_{2}^{[\mathrm{a}]}$ & 4. $\mathrm{Et}_{2} \mathrm{O}$ & 4. $\mathrm{PMe}_{3}$ & 4. $\mathrm{P}(\mathrm{OMe})_{3}$ & 4. $\mathrm{PPr}_{3}^{i}$ & 4. CNXyl & 7 \\
\hline Mo-Mo & $2.086(2)$ & $2.095(1)$ & $2.097(1)$ & $2.107(1)$ & $2.098(1)$ & $2.102(1)$ & $2.117(1)$ & $2.104(1)$ \\
\hline Mo- $\mathrm{C}_{\text {aryl }}$ & 2.192(2) & $2.187(3)$ & $2.164(3)$ & $2.176(3)$ & $2.181(3)$ & $2.193(2)$ & $2.186(3)$ & $2.229(3)$ \\
\hline Mo- $\mathrm{C}_{\text {arene }}$ & $2.572(2)^{[b]}$ & $2.780(2)^{[c]}$ & $2.565(3)^{[b]}$ & $2.636(1)^{[b]}$ & $2.636(1)^{[b]}$ & $2.697(1)^{[b]}$ & $2.644(1)^{[b]}$ & $2.658(3)^{[b]}$ \\
\hline Mo-L & & & $2.250(2)$ & $2.491(2)$ & $2.478(1)$ & $2.569(1)$ & $2.118(4)$ & $2.211(3)^{[e]}, 2.318(3)^{[f]}$ \\
\hline Mo-Mo-C $\mathrm{C}_{\text {aryl }}$ & $103.28(4)$ & $99.24(10)$ & $98.49(8)$ & $97.85(8)$ & $99.51(9)$ & $98.54(6)$ & $97.88(9)$ & $98.45(7)$ \\
\hline Mo-Mo-(L) & & & $118.29(6)$ & $100.88(2)$ & $104.14(4)$ & $108.04(3)$ & $96.98(9)$ & $106.47(7)^{[\mathrm{e]}]}, 110.05(7)^{[\mathrm{ff}]}$ \\
\hline trans $-\mathrm{C}_{\text {aryl}}-\mathrm{Mo}-\mathrm{I}^{[\mathrm{d}]}$ & $165.36(6)$ & & $143.01(9)$ & $142.39(8)$ & $141.54(9)$ & $140.16(6)$ & $144.28(9)$ & $151.49(10)$ \\
\hline
\end{tabular}

[a] Structural and characterization data have already been reported in reference $6 \mathrm{a}$. [b] $\mathrm{M}-\mathrm{C}_{\text {arene }}$ interaction to ortho carbon. [c] $\mathrm{M}-\mathrm{C}_{\text {arene }}$ interaction to ipso carbon. [d] For compounds 1 and 4- $\mathrm{Et}_{2} \mathrm{O} \mathrm{C}_{\text {ary }}-\mathrm{Mo}-\mathrm{O}$ angles. [e] To $\mathrm{C}_{34}$ in Figure 6. [f] To $\mathrm{C}_{27}$ also in Figure 6.

\section{Solid-state molecular structures of new complexes}

The newly prepared compounds were characterized by X-ray crystallography. Figure 4 displays the molecular structure of

4. $\mathrm{OEt}_{2}$ while perspective views of the structure of the molecules of $4 \cdot \mathrm{PMe}_{3}, \mathbf{4} \cdot \mathbf{P}(\mathrm{OMe})_{3}$ and $\mathbf{4} \cdot \mathrm{PPr}^{i}{ }_{3}$ are collected in Figure 5. Figure 6 presents the structure of the bis-NHC complexes 7. The X-ray structures of some $\mathbf{5 \cdot L}$ and $\mathbf{6 \cdot} \mathbf{L}$ derivatives were also ascertained and can be found in the SI (Figures S7-S12). Table 1 collects some selected bond distances and angles for representative compounds. For comparative purposes, data for $\mathrm{Mo}_{2}\left(\mathrm{Ar}^{\mathrm{Xy} / 2}\right)\left(\mathrm{O}_{2} \mathrm{CMe}\right)_{3}, \quad \mathbf{1}$, and $\mathrm{Mo}_{2}\left(\mathrm{Ar}^{\mathrm{Xy} / 2}\right)_{2}\left(\mathrm{O}_{2} \mathrm{CH}\right)_{2}$ are also incorporated. ${ }^{[6]}$ Inspection of the above figures evidences the significant distortions that exist in comparison with the regular paddle-wheel geometry of the parent complex $\mathrm{Mo}_{2}\left(\mathrm{O}_{2} \mathrm{CMe}\right)_{4}{ }^{[16]}$ and with the somewhat distorted structure of the precursor ${ }^{[6]}$ $\mathrm{Mo}_{2}\left(\mathrm{Ar}^{\mathrm{xyl}}\right)\left(\mathrm{O}_{2} \mathrm{CMe}\right)_{3}, 1$. The deviations may be due to the large steric requirements of the $\mathrm{Ar}^{\prime}, \mathrm{I}^{-}$and other ligands present in these complexes and were anticipated by studies on other $\mathrm{Mo} \equiv \mathrm{Mo}$ complexes with bulky monodentate ligands. ${ }^{[9]}$ In compound 1 (structure II, Chart 1) the bulkiness of the Ar' group leads to a transoid $\mathrm{C}_{\text {aryl }}-\mathrm{Mo}-\mathrm{O}$ angle of $165.4^{\circ}$, with a concomitant increase $^{[6]}$ of the $\mathrm{C}_{\text {aryl-Mo-Mo }}$ angle to $103.3^{\circ}$ (Table 1). In

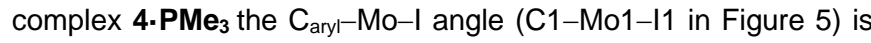
significantly smaller than expected for a trans ligand distribution $\left(142.4^{\circ}\right)$, while the Mo-Mo-I and Mo-Mo-P angles amount ca. 119.7 and $100.9^{\circ}$, respectively. For the related adducts 4. $\mathrm{P}(\mathrm{OMe})_{3}$ and 4. $\mathrm{PPr}_{3}{ }_{3}$ the $\mathrm{C}_{\text {aryl }}-\mathrm{Mo}-\mathrm{I}$ and Mo-Mo-I angles do not vary substantially from the above values but the Mo-Mo-P angle increases to about $104^{\circ}$ in the $\mathrm{P}(\mathrm{OMe})_{3}$ complex and $108^{\circ}$ in 4. $\mathrm{PPr}_{3}{ }_{3}$. Dihedral angles between the Mo-Mo-I and Mo-Mo-P planes in these complexes are of ca. 3.5․ Without underestimating the steric hindrance of the $\mathrm{P}$-donor ligand it appears that the voluminous iodide ligand, with a van der Waals radius $^{[7]}$ close to the Mo-Mo separations (2.04 vs. $2.10 \AA$ ), has a significant contribution to these distorsions.

For the objectives of this work, the most important metrics are those pertaining the $\mathrm{C}_{\text {aryl }}-\mathrm{Mo}-\mathrm{Mo}-\mathrm{C}_{\text {arene }}$ linkages of these complexes. Hence, our discussion will be centred in this analysis.
In all compounds, the Mo-Mo bond length is practically invariant (ca. 2.09-2.11, Table 1) and clusters around 2.10 A. Considering the diverse steric and electronic properties of the neutral $\mathrm{P}$ - and C-donor ligands present in our complexes, this constancy is remarkable and reveals that substitution of two bridging acetate groups by the monodentate $\mathrm{Ar}^{\prime}, \mathrm{I}^{-}$and $\mathrm{L}$ groups in complexes 4. $\mathbf{L}-\mathbf{6} \cdot \mathbf{L}$ has no appreciable effect in the length of the quadruple Mo-Mo bond. Variations in the Mo- $\mathrm{C}_{\text {arene }}$ separations in the range 2.57-2.78 Å do not affect either the Mo-Mo distance.

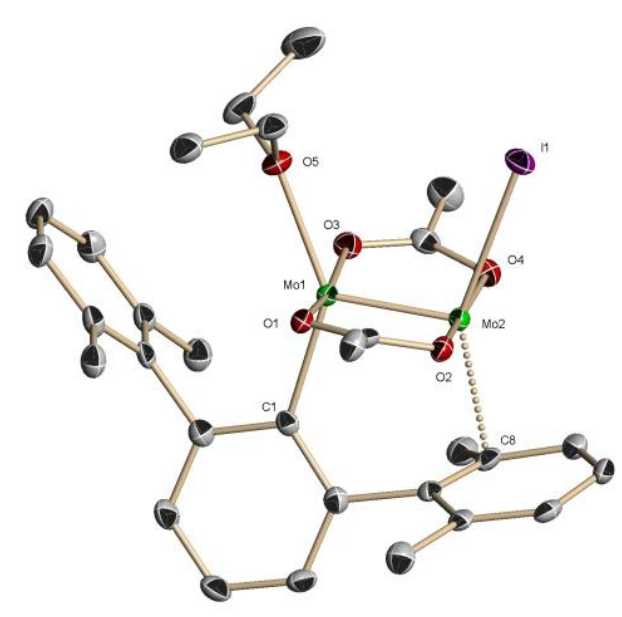

Figure 4. X-ray molecular structure of the ether adduct $\left[\mathrm{Mo}_{2}\left(\mathrm{Ar}^{\mathrm{Xyl_{2 }}}\right)(\mathrm{I})\left(\mathrm{O}_{2} \mathrm{CMe}\right)_{2}\left(\mathrm{OEt}_{2}\right)\right], \mathbf{4} \cdot \mathrm{OEt}_{2}$.

The Mo- $\mathrm{C}_{\text {aryl }}$ bond length in complexes $\mathbf{4 \cdot L}-\mathbf{6} \cdot \mathbf{L}$ does not change significantly with the nature of $L$, the shortest value corresponding to 4. $\mathrm{OEt}_{2}$, at 2.164(3) $\AA$ ( $\mathrm{C}_{\text {aryl }}$ transoid to $\mathrm{Et}_{2} \mathrm{O}$, with a $\mathrm{C}_{\text {aryl }}-\mathrm{Mo}-\mathrm{O}$ bond angle of $c a \cdot{ }^{143^{\circ}}$ ) and the longest (ca. 2.19 $\AA$ ) to 4. $\operatorname{PPr}_{3}^{i}$ and $\mathbf{5} \cdot \mathrm{PMe}_{3}\left(\mathrm{C}_{\text {aryl }}\right.$ transoid to $\mathrm{I}^{-}$, see Table 1$)$. However, in the cationic complex $7^{+}$where the $\mathrm{Ar}^{\prime}$ group has a transoid position relative to one of the $\mathrm{CN}_{2} \mathrm{C}_{2} \mathrm{Me}_{4}$ ligands (C12-Mo2-C19 angle of 
$\left.151.5^{\circ}\right)$, the Mo- $\mathrm{C}_{\text {aryl }}$ distance increases to ca. $2.23 \AA$. This observation denotes a large trans-influence of the $\mathrm{NHC}$ ligand that can indeed be advanced on the basis of its calculated ${ }^{[17]}$ Tolman electronic parameter (TEP) of $2051.7 \mathrm{~cm}^{-1}$. On the other hand, the late position expected for the Ar' group in a transinfluence series on account of that experimentally determined for the $\mathrm{C}_{6} \mathrm{H}_{5}$ ligand in square-planar $\mathrm{Pt}(\mathrm{II})$ complexes, ${ }^{[18]}$ is evidently responsible for the substantial difference in the Mo-C bonds to the $\mathrm{NHC}$ ligands of $7^{+}$. Consistent with the weaker Mo2-C8 bond to the flanking arene, the carbene trans to it has a much shorter Mo2-C34 bond $(2.211(3) \AA)$ than the carbene trans to the $\sigma$ bonded aryl, Mo1-C27 (2.318(3) $\AA$ ). The strong trans-influence foreseen for $A r^{\prime}$ ligands also explains the longer Mo-I bonds in complexes 4. $\mathrm{L}\left(\mathrm{L}=\mathrm{PMe}_{3}, \mathrm{P}(\mathrm{OMe})_{3}, \mathrm{PPr}_{3}^{i}\right.$ and $\left.\mathrm{CNXyl}\right)$ in comparison with the ether adducts $4 \cdot \mathbf{O E t}_{2}-\mathbf{6} \cdot \mathrm{OEt}_{2}$. In the former compounds the Mo-I distance has an average value of about $2.82 \AA$, whereas in the ether complexes is of $2.76 \AA$.

When the compounds reported here and the related bisterphenyl complexes reported elsewhere ${ }^{[6]}$ are jointly considered, a clear trend for a trans influence affecting the Mo- $\mathrm{C}_{\text {arene }}$ distances is revealed. Thus, the weakening effect on the Mo- $\mathrm{C}_{\text {arene }}$ distance increases depending on the nature of the trans donor atom, from weaker to stronger: O (2.55-2.57 $\AA$ ) I $(2.57 \AA)<\mathrm{C}(2.64-2.66 \AA$ in 7 and 4 . CNXyl $) \sim \mathrm{P}(2.64-2.69 \AA)<$
$\mathrm{C}_{\text {aryl }}(2.76-2.80 \AA \AA)$.

Regarding the Mo- $\mathrm{C}_{\text {arene }}$ interaction, before discussing our results it is pertinent to cite some literature precedents. In Power's Ar'CrCrAr' molecules, ${ }^{[4]}$ the $\mathrm{Cr}-\mathrm{C}_{\text {arene }}$ distance of $2.29 \AA$ was found to be ca. $7.5 \%$ longer than the $\mathrm{Cr}-\mathrm{C}_{\text {aryl }}$ bond $(2.13 \AA$ ). On the basis of quantum mechanical calculations the $\mathrm{Cr}-\mathrm{C}_{\text {arene }}$ interaction was viewed as a feeble one that causes only a small weakening of the quintuple bond. ${ }^{[5]}$ Besides, an also feeble $\mathrm{Cr}-\mathrm{C}_{\text {arene }}$ interaction was recently disclosed in the cationic bimetallic complex $(\mathrm{OC})_{4} \mathrm{Cr}\left(\mu-\mathrm{CPh}_{2}\right) \mathrm{Au}\left(\mathrm{PCy}_{3}\right)^{+}$, where there is a $\mathrm{Cr}-\mathrm{C}_{\text {arene }}$ contact of $2.28 \AA$ to the ipso carbon atom of one of the carbene phenyl substituents. ${ }^{[19]}$ This contact is $7 \%$ longer than the $\mathrm{Cr}-\mathrm{C}_{\text {carbene }}$ bond and whereas it results in important structural consequences, in accordance with DFT calculations it does not imply significant bonding interaction between the ipso carbon and chromium atoms. ${ }^{[19]}$ It must be said, however, that these $\mathrm{Cr}-\mathrm{C}_{\text {arene }}$ distances are similar to those found in $\pi$-bonded arene complexes, with an average value of 2.24(6) $\AA$ for structures in the CSD.

In the new complexes $\mathbf{4 \cdot L - 7}$, as well as in the precursor compounds $\mathbf{1 - 3}$, the terphenyl-bound molybdenum atom Mo1 displays a distorted square-pyramid coordination geometry with the other metal atom, Mo2, at the apex. Disregarding for the time
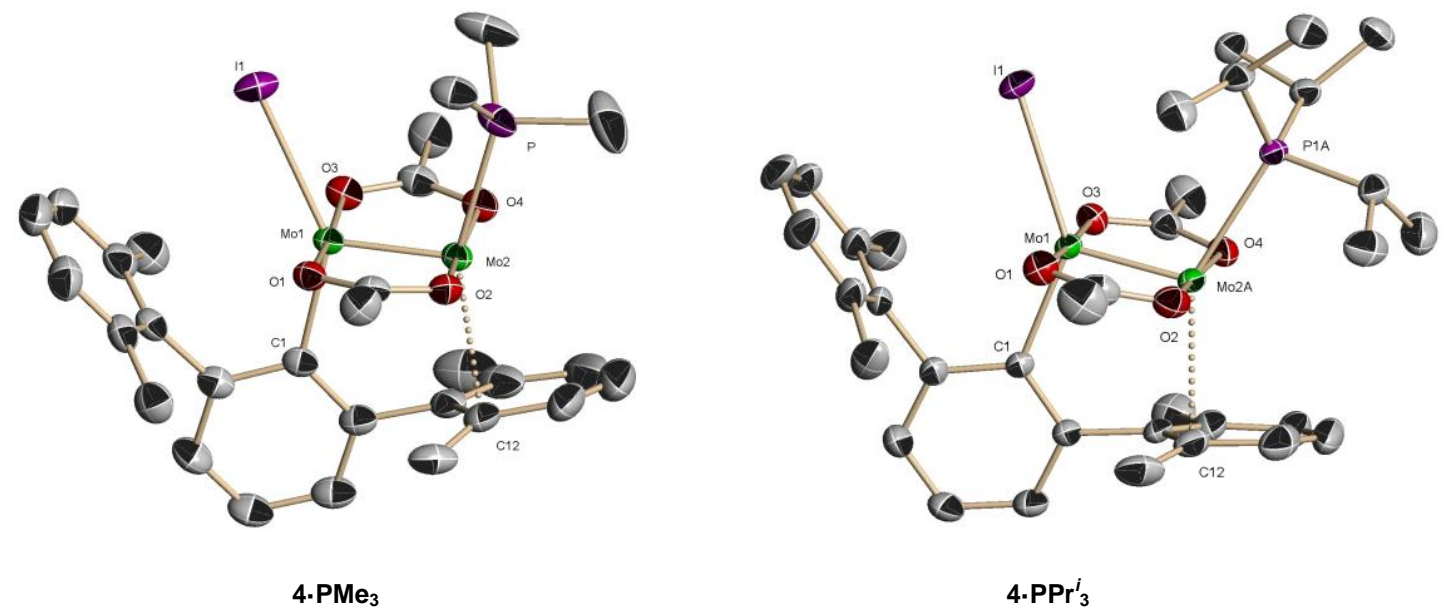

4. $\cdot \mathrm{PMe}_{3}$

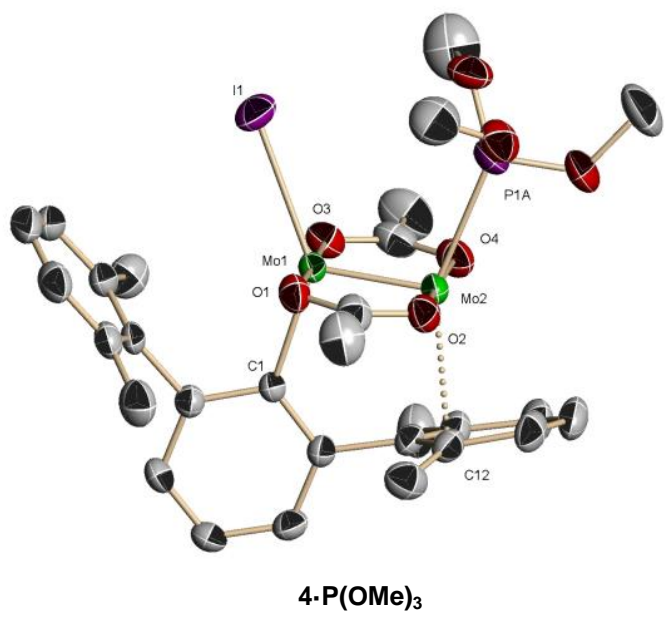

Figure 5. X-ray molecular structures of compound $\left[\mathrm{Mo}_{2}\left(\mathrm{Ar}^{\mathrm{Xyl}}\right)(\mathrm{I})\left(\mathrm{O}_{2} \mathrm{CMe}\right)_{2}(\mathrm{~L})\right]$ with $\mathrm{P}$-donor ligand. 
being the secondary Mo- $\mathrm{C}_{\text {arene }}$ interaction, Mo2 has a four coordinated structure also derived from a square-pyramid but with an empty basal site. The molecular geometry of the terphenyl ligand places one of the flanking aryl rings in the proximity of this empty coordination site so that for each of the compounds investigated either its ipso or one of the ortho carbon atoms (or both, vide infra) gets closer to Mo2 than the other $\mathrm{C}_{\text {arene }}$ atoms. For the mono-terphenyl complexes $\mathrm{Mo}_{2}\left(\mathrm{Ar}^{\prime}\right)\left(\mathrm{O}_{2} \mathrm{CR}\right)_{3},{ }^{[6]}$ and also for compounds $\mathbf{4} \cdot \mathbf{O} \mathrm{Et}_{2}$ and $\mathbf{5} \cdot \mathrm{PMe}_{3}$, the shortest $\mathrm{Mo}-\mathrm{C}_{\text {arene }}$ contact to one of the ortho carbon atoms has a distance of ca. $2.58 \AA$ while in all other complexes $4 \cdot \mathbf{L}-\mathbf{6} \cdot \mathbf{L}$, this distance is longer and has an average value of $2.64 \AA$. In some of these complexes, e.g. 4.PMe $\mathrm{PM}_{3}$, there is another only slightly longer contact to the ipso carbon at ca. $2.71 \AA$, so that the interaction between the flanking arene and the Mo atom may be viewed as approaching $\eta^{2}$. It is pertinent to note that complexes $\mathbf{4} \cdot \mathrm{PMe}_{3}$ and 4. $\mathrm{P}(\mathrm{OMe})_{3}$, that possess similar structure but $\mathrm{P}$-donor ligands of different electron donor properties (TEP of 2064 and $2080 \mathrm{~cm}^{-1}$, respectively ${ }^{[20]}$ exhibit $\mathrm{Mo}-\mathrm{C}_{\text {arene }}$ interactions of identical length (ca. $2.64 \AA$ ). In the bis-terphenyl complex $\mathrm{Mo}_{2}\left(\mathrm{Ar}^{\mathrm{Xyl} / 2}\right)_{2}\left(\mathrm{O}_{2} \mathrm{CH}\right)_{2}$, also included in Table 1, $d\left(\right.$ Mo- $\left.\mathrm{C}_{\text {arene }}\right)$ increases to $2.78 \AA \AA^{[6]}$

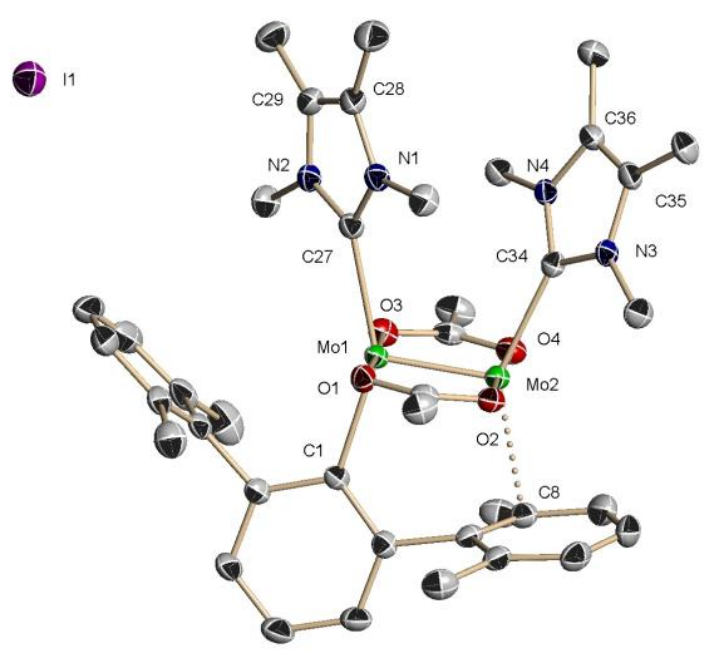

Figure 6. X-ray molecular structure of $\left[\mathrm{Mo}_{2}\left(\mathrm{Ar}^{\mathrm{Xyl} / 2}\right)\left(\mathrm{O}_{2} \mathrm{CMe}\right)_{2}\left(\mathrm{CN}_{2} \mathrm{C}_{2} \mathrm{Me}_{4}\right)_{2}\right] \mathrm{l}, 7$

Comparison of Mo- $\mathrm{C}_{\text {aryl }}$ and $\mathrm{Mo}-\mathrm{C}_{\text {arene }}$ distances in these complexes reveals that the interaction with the flanking aryl is characterized by a Mo- $\mathrm{C}_{\text {arene }}$ distance that is $15-20 \%$ longer than the $\sigma \mathrm{Mo}-\mathrm{C}_{\text {aryl }}$ bond. Furthermore, the Mo- $\mathrm{C}_{\text {arene }}$ contacts are also significantly longer than $\mathrm{Mo}-\mathrm{C}_{\text {arene }}$ bonds in classical mononuclear $\mathrm{Mo}(\mathrm{II})$ arenes (e.g. 2.26-2.35 $\AA$ in $\mathrm{MoMe}_{2}\left(\eta^{6}\right.$ $\left.\mathrm{C}_{6} \mathrm{H}_{6}\right)\left(\mathrm{PMe} \mathrm{PM}_{2} \mathrm{Ph}\right)^{\left[{ }^{[21]}\right.}$ Therefore, X-ray data suggest that in terms of electron density sharing, the interactions between Mo2 and $\mathrm{C}_{\text {arene }}$ are weak. Although for the complexes with the longest Mo2- $\mathrm{C}_{\text {arene }}$ separations one could think that the proximal flanking aryl ring has mostly a protective role and acts as steric guard for the low-coordinate Mo2 atom, a detailed analysis of this interesting structural and bonding problem by means of theoretical calculations presented in the following section, as well as a parallel study on aryls coordinated in a $\pi: \eta^{1}$-mode to platinum atoms, point to the two-electron donor role played by such rings. ${ }^{[22]}$

\section{Computational studies}

Arene coordination to $\mathrm{Mo}_{2}{ }_{2}$ fragments. Modelization of $\left[\mathrm{Mo}_{2}\left(\mathrm{Ar}^{\mathrm{Xyl} / 2}\right)\left(\mathrm{O}_{2} \mathrm{CMe}\right)_{3}\right]^{[6 \mathrm{~b}]}$ as a complex with an independent benzene ring coordinated in a monohapto mode in $\left[\mathrm{Mo}_{2}(\mathrm{H})\left(\mathrm{O}_{2} \mathrm{CMe}\right)_{3}\left(\eta^{1}-\mathrm{C}_{6} \mathrm{H}_{6}\right)\right]$ should allow us to get an estimate of the bonding energy between the side phenyl group of the terphenyl ligand and the Mo2 unit. Figure 7 presents the potential energy curve for the dissociation of an independent benzene ring to the $\mathrm{Mo}_{2}(\mathrm{H})\left(\mathrm{O}_{2} \mathrm{CMe}\right)_{3}$ fragment. A fitting of the calculated energies to a Morse potential yields $\mathrm{Mo}-\mathrm{C}=2.645 \AA$ and $\mathrm{a}$ dissociation enthalpy of $9.0 \mathrm{kcal} / \mathrm{mol}$, while full optimization gives practically the same distance $(2.644 \AA)$, in excellent agreement with that found experimentally for the anchored phenyl side groups, and a free energy of dissociation of $13.3 \mathrm{kcal} / \mathrm{mol}$ at room temperature.

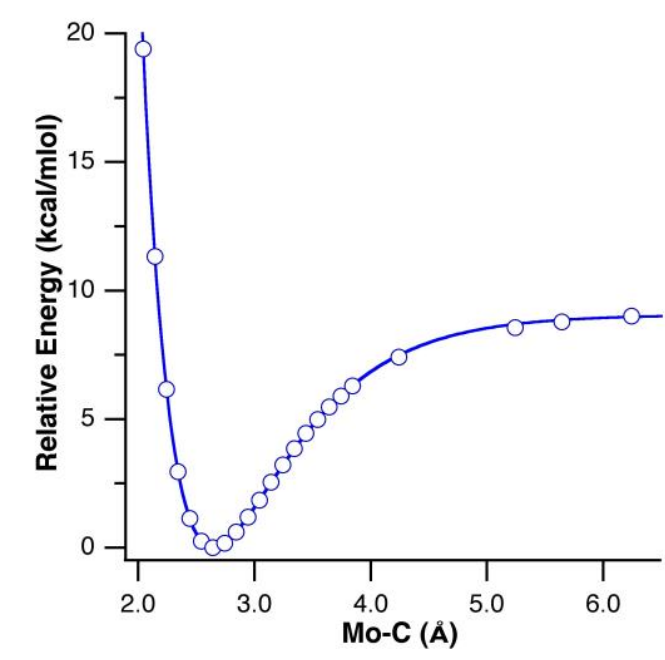

Figure 7. Potential energy of $\left[\mathrm{Mo}_{2}(\mathrm{H})\left(\mathrm{O}_{2} \mathrm{CMe}\right)_{3}\left(\eta^{1}-\mathrm{C}_{6} \mathrm{H}_{6}\right)\right]$ as a function of the shortest Mo-C(benzene) distance, relative to that of the optimized geometry.

In the subsequent discussion, we will often need to find a systematic way of classifying the hapticity of a coordinated arene as $\eta^{1}, \eta^{2}$ or $\eta^{3}$. While some intermediate situations may exist, in general plotting two structural parameters in a "hapticity map", as discussed by us elsewhere, has been found useful to discriminate the low hapticities. In brief, our proposal consists in comparing the three shortest $M-C_{\text {arene }}$ distances $\left(d_{1}<d_{2}<d_{3}\right)$ by means of the ratios defined in equations 1 and 2. A scatterplot of those ratios in a hapticity map has three regions that can be approximately associated with $\eta^{1}, \eta^{2}$ or $\eta^{3}$ coordination modes, although with somewhat imprecise borderline regions (Figure 8).

$$
\begin{aligned}
& \rho_{1}=d_{2} / d_{1} \\
& \rho_{2}=d_{3} / d_{1}
\end{aligned}
$$

If the Mo-C arene distance ratios obtained for the models are plotted in such a hapticity map, the benzene ring of $\left[\mathrm{Mo}_{2}(\mathrm{H})\left(\mathrm{O}_{2} \mathrm{CMe}\right)_{3}\left(\mathrm{C}_{6} \mathrm{H}_{6}\right)\right]$ can be clearly classifed as $\eta^{2}-$ 
coordinated, at variance with the anchored aryl groups in the experimental structures, that place themselves in regions closer to the $\eta^{1}-\eta^{3}$ border (Figure 8). These results indicate that the $\eta^{2}$. coordination is the preferred one for an independent benzene ring, and it seems reasonable to assume that the anchoring of the phenyl groups in the terphenyl complexes can force the slightly less favorable $\eta^{1}$ or $\eta^{3}$ coordination modes, most clearly seen in $\mathbf{2}$, 4. $\mathrm{OEt}_{2}$, 4.P(OMe $)_{3}$ and $\mathrm{Mo}_{2}\left(\mathrm{Ar}^{\mathrm{Xy|}}\right)_{2}\left(\mathrm{O}_{2} \mathrm{CH}\right)_{2}$. To verify this assumption we discuss next calculations on more realistic models.

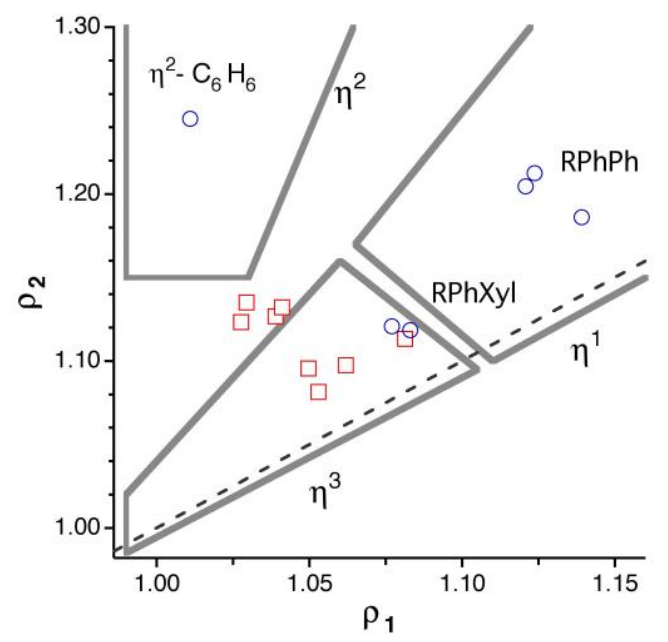

Figure 8. Hapticity map that represents the ratios of the three shortest $M-C$ distances defined in equations 1 and 2 , with limits of the $\eta^{1}-, \eta^{2}$ - and $\eta^{3}$ - regions set arbitrarily, in which the flanking arene rings of calculated $\left[\mathrm{Mo}_{2}(\mathrm{H})\left(\mathrm{O}_{2} \mathrm{CMe}\right)_{3}\left(\eta^{2}-\mathrm{C}_{6} \mathrm{H}_{6}\right)\right]$ and $\left[\mathrm{Mo}_{2}\left(\mathrm{R}-\mathrm{Ph}-\mathrm{R}^{\prime}\right)\left(\mathrm{O}_{2} \mathrm{CMe}\right)_{3}\right]$ complexes $(\mathrm{R}=\mathrm{H}, \mathrm{Ph}$ $\mathrm{Xyl} ; \mathrm{R}^{\prime}=\mathrm{Ph}, \mathrm{Xyl}$ ) (circles) and experimental (squares) structures are represented.

Optimization of anchored analogues $\left[\mathrm{Mo}_{2}\left(\sigma-\mathrm{C}_{6} \mathrm{H}_{4}-\pi-\right.\right.$ $\left.\mathrm{R})\left(\mathrm{O}_{2} \mathrm{CMe}\right)_{3}\right](\mathrm{R}=\mathrm{Ph}, \mathrm{Xyl})$, in which the hydride and benzene ligands have been replaced by a biaryl group results in coordination of the flanking arene through its ortho carbon atom, as in the experimental structures, and at the same Mo-C distance ( 2.570 and $2.571 \AA$ for the calculated and experimental structures respectively). Unlike the experimental structures, and in spite of the excellent agreement in the Mo-C bond distance, this calculated compound is unequivocally identified as a monohapto species and has also a much larger Mo-C...C flap angle $\beta$ (see structure A) than the experimental structure (99 and 78-84을 respectively).

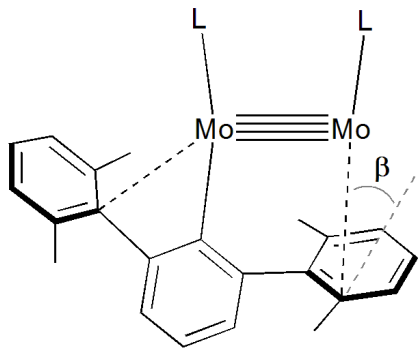

A

Searching for the cause of the different hapticity and flap angle in our model biphenyl compounds $\left[\mathrm{Mo}_{2}\left(\sigma-\mathrm{C}_{6} \mathrm{H}_{4}-\pi-\right.\right.$ $\mathrm{R})\left(\mathrm{O}_{2} \mathrm{CMe}\right)_{3}$ ], we have performed geometry optimizations for the series of terphenyl compounds $\left[\mathrm{Mo}_{2}\left(\mathrm{RC}_{6} \mathrm{H}_{3} \mathrm{R}^{\prime}\right)\left(\mathrm{O}_{2} \mathrm{CMe}\right)_{3}\right]$, where $\mathrm{R}=\mathrm{Ph}, \mathrm{Xyl} ; \mathrm{R}^{\prime}=\mathrm{Ph}, \mathrm{Xyl}$. Substituting the biphenyl by a terphenyl group $\left(R=R^{\prime}=P h\right)$ does not significantly affect the hapticity of the side phenyl ring $\left(\rho_{1}=1.14, \rho_{2}=1.19\right)$. Introduction of methyl groups at the ortho positions of the distal aryl group $\left(R=X y l, R^{\prime}=\right.$ $\mathrm{Ph})$ does not change the situation either $\left(\rho_{1}=1.12, \rho_{2}=1.20\right.$, and flap angle of $97^{\circ}$ ). It is the presence of the ortho methyl groups in the $\pi$-coordinated arene ring (i.e., $R=P h, X y l ; R^{\prime}=X y l$ ) that places that phenyl ring close to the $\eta^{3}$ region where the experimental structures are $\left(\rho_{1}=1.08, \rho_{2}=1.12\right)$ and puts down the phenyl flap (M-C...C angle of $\left.86^{\circ}\right)$, with a simultaneous increase of the Mo $\cdots C$ distance. It must also be noted that the isomeric compound $\left(R=X y l, R^{\prime}=P h\right)$ is slightly more stable in our calculations $(1.3 \mathrm{kcal} / \mathrm{mol})$ than the alternative isomer $(R=P h$, $\left.\mathrm{R}^{\prime}=\mathrm{Xyl}\right)$. It thus seems that the attachment of the flanking arene group to the $\sigma$-bonded ring prevents it from achieving an $\eta^{2}$ coordination and favours the $\eta^{1}$ mode, but the steric bulk introduced by the ortho methyl groups forces a somewhat longer Mo-C distance with the corresponding weakening of the $\eta^{1}$ interaction, which is in part compensated by a shift towards an $\eta^{3}$ mode via a smaller flap angle. It is worth mentioning in passing that the flanking arene rings in the quintuply bonded $\mathrm{Ar}^{\prime} \mathrm{CrCrAr}$ ' complexes reported by Power and co-workers ${ }^{[4]}$ occupy the same region in the hapticity map (not shown in Figure 8 for simplicity) than the $\mathrm{Mo}_{2}$ compounds presented here, and have similar flap angles as well.

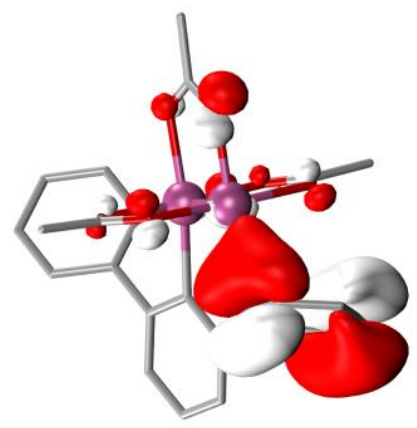

Figure 9. An occupied $\pi$ bonding $\mathrm{MO}$ of the flanking arene ring showing a bonding contribution from the $\mathrm{Mo}$ atom in $\left[\mathrm{Mo}_{2}\right.$ (terphenyl $\left.)\left(\mathrm{O}_{2} \mathrm{CMe}\right)_{3}\right]$. 

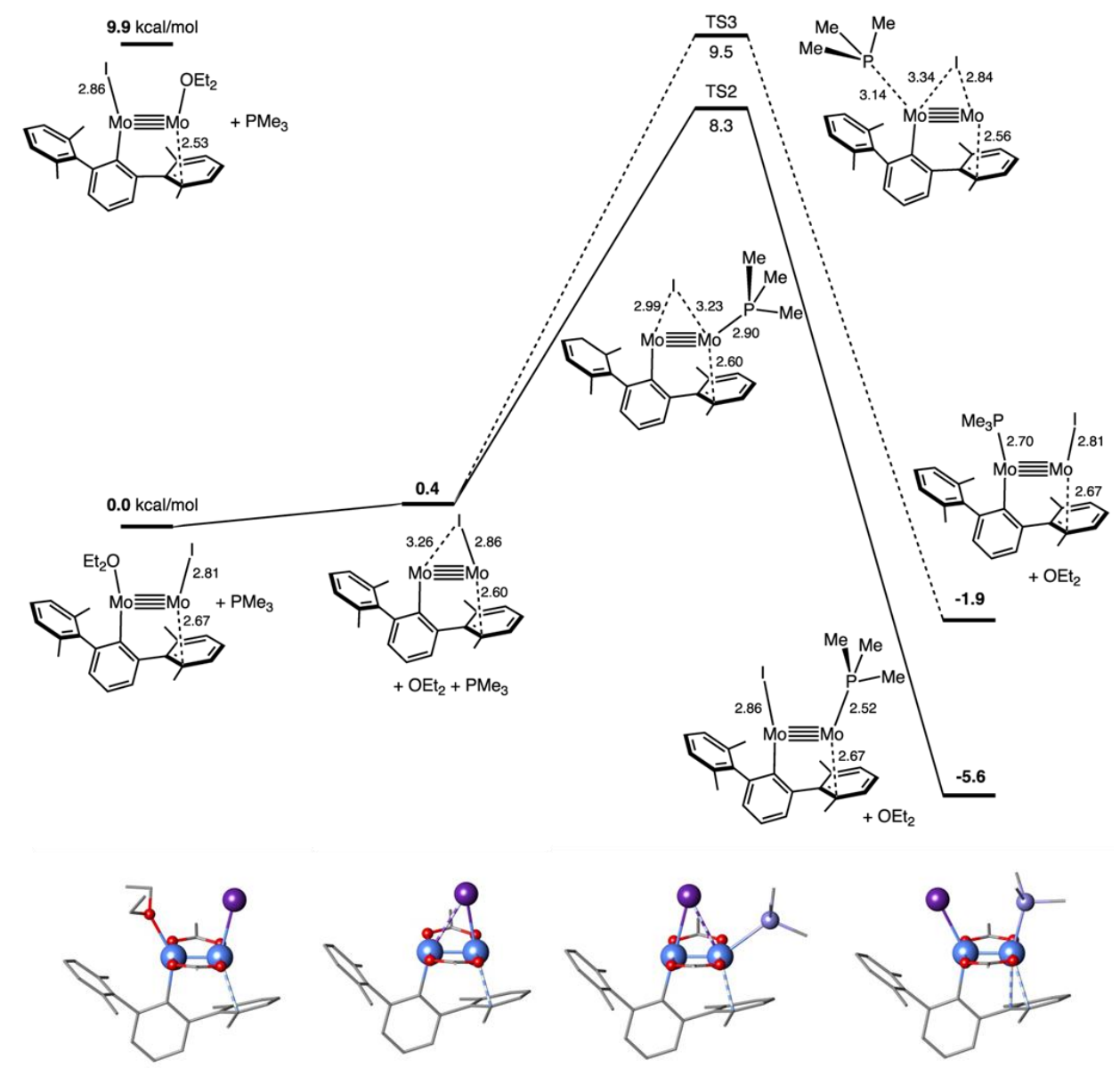

Figure 10. Above: Relative free energies at $298 \mathrm{~K}$ of the two isomers of $\left[\mathrm{Mo}_{2}\left(\mathrm{Ar}^{\mathrm{Xyl} 2}\right)(\mathrm{I})\left(\mathrm{O}_{2} \mathrm{CMe}\right)_{2}(\mathrm{~L})\right]\left(\mathrm{L}=\mathrm{Et}_{2} \mathrm{O}, \mathrm{PMe}_{3}\right)$, a dissociated intermediate $\left[\mathrm{Mo}_{2}\left(\mathrm{Ar}{ }^{\mathrm{Xyl} 2}\right)(\mu-\right.$ I) $\left(\mathrm{O}_{2} \mathrm{CMe}\right)_{2}$ ], and two transition states for the ligand substitution reaction. The acetate groups are omitted for clarity. Distances are given in A. Below: Calculated molecular structures of the four low-energy species found along the substitution pathway.

The existence of a bonding interaction between the $\pi$ system of the flanking arene and the Mo atom shows up in the significant mixing with a molybdenum atomic orbital (Figure 9). In addition, a topological analysis of the electron density shows a bond critical point between the metal atom and the $\eta^{1}$-coordinated carbon atom of the arene ring in the biaryl- and terphenyl complexes, and two $\mathrm{M}-\mathrm{C}$ bond critical points for the $\eta^{2}$-coordinated benzene. An interesting finding is the existence of a bond critical point between the non-bonded arene ring $\mathrm{R}$ and the Mo atom $\sigma$-bonded to the central phenyl group in the $\left[\mathrm{Mo}_{2}\left(\mathrm{RC}_{6} \mathrm{H}_{3} \mathrm{Ph}\right)\left(\mathrm{O}_{2} \mathrm{CMe}\right)_{3}\right]$ complexes, at quite long $\mathrm{Mo} \cdots \mathrm{C}$ distances ( 3.12 and $3.17 \AA$ for $\mathrm{R}=\mathrm{Ph}$ and $\mathrm{Xyl}$, respectively) along the Mo-Mo axis. When the flanking arene ring is a xylyl, that distance is slightly longer (3.23 and $3.30 \AA$ for $\mathrm{R}=\mathrm{Ph}$ and $\mathrm{Xyl}$, respectively), and the bond critical point vanishes, indicating a steric avoidance of such a weak non-bonding interaction. As argued below such an incipient interaction may be instrumental in facilitating the 1,2-shift fluxional process.

Wiberg calculated bond indices of the order of $0.1-0.2$ for the $\mathrm{M}-\mathrm{C}_{\text {arene }}$ contact in the $\eta^{1}$-coordinated species are consistent with the existence of bonding. Moreover, bond orders of around $0.05-0.10$ with the two neighboring carbon atoms indicate that the electron pair involved in the donation towards the metal atom is not fully localized and that electronically the coordination has a small $\eta^{3}$-character, regardless of the geometrical hapticity discussed above. For the $\eta^{2}$-bonded species the Wiberg bond indices also have similar values for the two $\mathrm{M}-\mathrm{C}$ bonds (between 0.1 and 0.2 ).

Substitution reactions on $\left[\mathrm{Mo}_{2}\left(\mathrm{Ar}^{\mathrm{Xyl}}\right)(\mathrm{I})\left(\mathrm{O}_{2} \mathrm{CMe}\right)_{2}(\mathrm{~L})\right]$. An intriguing geometrical feature of this family of compounds is that the starting complex $\left(\mathrm{L}=\mathrm{Et}_{2} \mathrm{O}\right)$ has the iodide ligand coordinated in trans to the same Mo atom than the $\sigma$-bonded phenyl ring, whereas substitution of the ether by ligands such as $\mathrm{PMe}_{3}$, $\mathrm{P}(\mathrm{OMe})_{3}, \mathrm{PPr}_{3}^{i}$, and $\mathrm{CNXYl}$ results in the alternative isomer with the iodide trans to the $\pi: \eta^{1}$ coordinated phenyl ring. Our DFT calculations on the $\left[\mathrm{Mo}_{2}\left(\mathrm{Ar}^{\mathrm{Xyl} 2}\right)(\mathrm{I})\left(\mathrm{O}_{2} \mathrm{CMe}\right)_{2}(\mathrm{~L})\right]$ complexes $(\mathrm{L}=$ $\mathrm{Et}_{2} \mathrm{O}, \mathrm{PMe}_{3}$ ) (Figure 10) consistently indicate the experimental isomer to be the most stable one. Moreover, the dissociation of $\mathrm{Et}_{2} \mathrm{O}$ is calculated to cost barely $0.4 \mathrm{kcal} / \mathrm{mol}$, and to yield an intermediate with a bridging iodide. Since the entering ligand can in principle react with either Mo atom, it seems reasonable to assume that the steric protection provided by the unbonded xylyl 
group favours the attack on the Mo atom with the $\eta^{1}$-coordinated xylyl to yield the thermodynamically preferred isomer.

\section{Conclusion}

The clear-cut experimental studies described in this paper provide an easy access to a series of terphenyl complexes of the $\mathrm{Mo} \equiv$ Mo core with composition $\mathrm{Mo}_{2}\left(\mathrm{Ar}^{\prime}\right)(\mathrm{I})\left(\mathrm{O}_{2} \mathrm{CMe}\right)_{2}(\mathrm{~L})$, where the nature of the $L$ group may be varied to accommodate ligands of assorted electronic and steric properties. This has allowed to develop a systematic structural and computational study of the so-called secondary interaction present in multiply bonded dimetal complexes of terphenyl ligands. ${ }^{[5,6]}$ For the model complex $\left[\mathrm{Mo}_{2}(\mathrm{H})\left(\mathrm{O}_{2} \mathrm{CMe}\right)_{3}\left(\mathrm{C}_{6} \mathrm{H}_{6}\right)\right]$, a significant bonding character has been computed for $\eta^{2}-\mathrm{C}_{6} \mathrm{H}_{6}$ coordination to the closer Mo atom, with a calculated bond dissociation free energy of 13.3 $\mathrm{kcal} / \mathrm{mol})$. In $\mathrm{Mo}_{2}\left(\mathrm{RC}_{6} \mathrm{H}_{3} \mathrm{R}^{\prime}\right)\left(\mathrm{O}_{2} \mathrm{CMe}\right)_{3}$ model or isolated complexes, calculations predict consistently $\eta^{1}$ binding of a flanking aryl ring, with the shortest $\mathrm{Mo}-\mathrm{C}_{\text {arene }}$ distances to an ortho carbon atom in the range $2.56-2.65 \AA$.

For the above monoterphenyls and for related bis-terphenyl complexes reported elsewhere, ${ }^{[6]}$ the experimental Mo- $\mathrm{C}_{\text {arene }}$ distance vary in the interval 2.57-2.78 $\AA$ and cluster in the upper part of the range found for $\pi$-bonded olefins (ca. 2.6-2.7 $\AA$ ). ${ }^{[22]}$ Comparison of these distances with the sums of the covalent and van der Waals radii (2.17 and $4.22 \AA$, respectively) indicate the existence of a Mo- $\mathrm{C}_{\text {arene }}$ bonding interaction, which is nevertheless weaker than the bonds in classical mononuclear $\mathrm{Mo}(\mathrm{II})-\eta^{6}-\mathrm{C}_{6} \mathrm{H}_{6}$ complexes. ${ }^{[21]}$

With reference to $\mathrm{Ar}^{\mathrm{Xyl} 2}$ derivatives as representative examples, DFT calculations disclose that the different stereochemistry of 4. $\mathrm{OEt}_{2}$ and $\mathbf{4} \cdot \mathrm{PMe}_{3}$ (and by extension of other $\mathbf{4} \cdot \mathbf{L}$ adducts) is determined by thermodynamic factors. Besides, the calculations unfold a readily accessible iodide-bridged transition state for the facile conversion of $\mathbf{4 \cdot \mathrm { OEt } _ { 2 }}$ into compounds $\mathbf{4} \cdot \mathbf{L}$.

\section{Experimental Section}

\section{General Consideration}

All manipulations were carried out using standard Schlenk and glove-box techniques, under an atmosphere of argon and of high purity nitrogen, respectively. All solvents were dried and degassed prior to use, and stored over $4 \AA$ molecular sieves. Toluene $\left(\mathrm{C}_{7} \mathrm{H}_{8}\right)$, n-pentane $\left(\mathrm{C}_{5} \mathrm{H}_{12}\right)$ and $n$-hexane $\left(\mathrm{C}_{6} \mathrm{H}_{14}\right)$ were distilled under nitrogen over sodium. Tetrahydrofuran (THF) and diethyl ether were distilled under nitrogen over sodium/benzophenone. $\left[D_{6}\right]$ Benzene and $\left[D_{8}\right]$ THF were distilled under argon over sodium/benzophenone; $\left[D_{8}\right]$ toluene was distilled under argon over sodium. The quadruply bonded $\left[\mathrm{Mo}_{2}\left(\mathrm{O}_{2} \mathrm{CR}\right)_{4}\right](\mathrm{R}$ $=\mathrm{CH}_{3}, \mathrm{CF}_{3}$ ) complexes, ${ }^{[23,24]}$ as well as the different terphenyl iodides [Ar'l] (Ar' $=\mathrm{Ar}^{\mathrm{xyl} 2}$ and $\left.\mathrm{Ar}^{\mathrm{Mes} 2}\right),{ }^{[25]}$ their corresponding lithium salts, $\left[\mathrm{LiAr}^{\prime}\right],{ }^{[26]}$ and $\left[\mathrm{Mgl}_{2}\right]^{[27]}$ were prepared according to literature methods. $\mathrm{Mo}_{2}\left(\mathrm{O}_{2} \mathrm{CMe}\right)_{4}$ was washed with toluene at $100{ }^{\circ} \mathrm{C}$ to remove any acidic residue. Complexes $\left[\mathrm{Mo}_{2}\left(\mathrm{Ar}^{\prime}\right)\left(\mathrm{O}_{2} \mathrm{CR}\right)_{3}\right]$ $\left[A r^{\prime}=A r^{X y l_{2}}, R=M e(1) ; A r^{\prime}=A r^{M e s} 2, R=M e(2) ; A r^{\prime}=A r^{x y l_{2}}, R=C F_{3},(3)\right]$ employed as metal precursors for this work were prepared according to methods described in the literature. ${ }^{[6 a]}$ All other compounds were commercially available and were used as received. Solution NMR spectra were recorded on Bruker AMX-300, DRX-400 and DRX-500 spectrometers. The resonance of the solvent was used as the internal standard, chemical shifts are reported relative to TMS and the NMR signals of fluorinated derivatives are reported relative to $\mathrm{CFCl}_{3}$. UV-Visible spectra were recorded on a PerkinElmer Lambda 750 spectrometer. IR spectra were recorded on a Bruker Tensor 27 and for elemental analyses a LECO TruSpec CHN elementary analyzer, was utilized. X-ray crystallographic data for compounds $\mathbf{4 \cdot L , ~ 5 \cdot L , ~ 6 \cdot L ~ a n d ~} 7$ (CCDC 1008636
1008647), contain the supplementary crystallographic data for this paper. These data can be obtained free of charge from The Cambridge Crystallographic Data Centre via www.ccdc.cam.ac.uk/data_request/cif.

Syntheses of complexes $\left[\mathrm{Mo}_{2}\left(\mathrm{Ar}^{\mathrm{Xyl}} \mathrm{l}_{2}\right)(\mathrm{I})\left(\mathrm{O}_{2} \mathrm{CMe}\right)_{2}(\mathrm{~L})\right]$, $\left(\mathrm{L}=\mathrm{Et}_{2} \mathrm{O}\left(4 \cdot \mathrm{OEt}_{2}\right)\right.$, CNXyl (4. CNXyl), $\mathrm{PMe}_{3}\left(4 \cdot \mathrm{PMe}_{3}\right), \mathrm{PPr}_{3}^{i}\left(4 \cdot \mathrm{PPr}_{3}^{i}\right), \mathrm{P}(\mathrm{OMe})_{3}\left(4 \cdot \mathrm{P}(\mathrm{OMe})_{3}\right)$, and $\mathrm{CN}_{2} \mathrm{C}_{2} \mathrm{Me}_{4}(7)$ ).

\section{Synthesis of $4 \cdot \mathrm{OEt}_{2}$.}

$\mathrm{Mgl}_{2}(140 \mathrm{mg}, 0.5 \mathrm{mmol})$ and $\mathrm{Mo}_{2}\left(\mathrm{Ar}^{\mathrm{Xyl}}\right)\left(\mathrm{O}_{2} \mathrm{CMe}\right)_{3}$, (1), (655 mg, $\left.1.0 \mathrm{mmol}\right)$ were placed in a Young ampoule inside the dry box. The reaction flask was then cooled to $-30{ }^{\circ} \mathrm{C}$ and $25 \mathrm{~mL}$ of diethyl ether were added. A color change from dark red to blue-violet was observed when the reaction mixture was allowed to reach room temperature with continuous stirring during 12 hours. Then, the reaction solution was centrifuged and the filtrate was transferred to a Schlenk tube, concentrated to a volume of ca. $10 \mathrm{~mL}$ and stored at $-23 \stackrel{\circ}{\circ} \mathrm{C}$ to obtain complex $4 . \mathrm{OEt}_{2}$ as a blue-violet crystalline solid which was separated by filtration and dried under vacuum for 3 hours. Yield: $440 \mathrm{mg}(55 \%) .{ }^{1} \mathrm{H}$ NMR $\left(500 \mathrm{MHz}, \mathrm{C}_{6} \mathrm{D}_{6}, 10^{\circ} \mathrm{C}\right): \delta=1.07\left(\mathrm{t}, 30 \mathrm{H},{ }^{3} \mathrm{~J}_{\mathrm{HH}}=7.0 \mathrm{~Hz}, \mathrm{OCH}_{2} \mathrm{CH}_{3}\right), 2.09(\mathrm{~s}, 6 \mathrm{H}$, $\left.\mathrm{Me}_{\mathrm{Xyl}}\right)^{\prime}, 2.23\left(\mathrm{~s}, 6 \mathrm{H}, \mathrm{Me}_{\mathrm{Xyl}}\right), 2.59\left(\mathrm{~s}, 6 \mathrm{H}, \mathrm{Me}_{\mathrm{OAc}}\right), 3.22\left(\mathrm{q}, 20 \mathrm{H},{ }^{3} \mathrm{~J}_{\mathrm{HH}}=7.0 \mathrm{~Hz}\right.$, $\mathrm{OCH}_{2} \mathrm{CH}_{3}$ ), 6.23 (br. t, $1 \mathrm{H},{ }^{3} \mathrm{~J}_{\mathrm{HH}}=7.0 \mathrm{~Hz}, p-\mathrm{Xyl}$ )', 6.56 (br. d, $2 \mathrm{H},{ }^{3} \mathrm{~J}_{\mathrm{HH}}=7.0 \mathrm{~Hz}$, $m$-Xyl'), 6.64 (br. d, $1 \mathrm{H}, m-\mathrm{C}_{6} \mathrm{H}_{3}$ ), 6.71 (br. s, $3 \mathrm{H}, m-\mathrm{Xyl}$ and $p-\mathrm{Xyl}$ ), 6.89 (br. d, $\left.1 \mathrm{H}, m-\mathrm{C}_{6} \mathrm{H}_{3}\right), 7.25\left(\mathrm{t}, 1 \mathrm{H},{ }^{3} \mathrm{~J}_{\mathrm{HH}}=7.5 \mathrm{~Hz}, p-\mathrm{C}_{6} \mathrm{H}_{3}\right) \mathrm{ppm} ;{ }^{13} \mathrm{C} \mathrm{NMR}\left(125 \mathrm{MHz}, \mathrm{C}_{6} \mathrm{D}_{6}\right.$, $\left.\left.10{ }^{\circ} \mathrm{C}\right): \delta=15.11\left(\mathrm{OCH}_{2} \mathrm{CH}_{3}\right), 20.8\left(\mathrm{Me}_{\mathrm{Xyl}}\right), 22.6\left(\mathrm{Me}_{\mathrm{Xy}}\right)^{\prime}\right), 23.8\left(\mathrm{Me}_{\mathrm{OAC}}\right), 65.7$ $\left(\mathrm{OCH}_{2} \mathrm{CH}_{3}\right), 124.6,125.7\left(m-\mathrm{C}_{6} \mathrm{H}_{3}\right.$ and $\left.m^{\prime}-\mathrm{C}_{6} \mathrm{H}_{3}\right), 126.2(m-\mathrm{Xyl}), 126.4\left(p-\mathrm{C}_{6} \mathrm{H}_{3}\right)$ 126.8 ( $p$-Xyl), 129.5 (p-Xyl'), 129.6 (m-Xyl'), 136.4 (o-Xyl), 137.1 (o-Xyl'), 139.0 (ipso-Xyl'), 142.8 (ipso-Xyl), 146.0, $147.2\left(o-\mathrm{C}_{6} \mathrm{H}_{3}\right.$ and o'- $\left.\mathrm{C}_{6} \mathrm{H}_{3}\right), 177.2\left(\mathrm{Mo}-\mathrm{C}_{\mathrm{ar}}\right)$, $184.6\left(\mathrm{O}_{2} \mathrm{CMe}\right) \mathrm{ppm}$. UV/Vis $\left(\mathrm{Et}_{2} \mathrm{O}\right) ; \lambda_{\max }(\varepsilon) 535 \mathrm{~nm}\left(1500 \mathrm{M}^{-1} \mathrm{~cm}^{-1}\right) ;\left(\mathrm{C}_{6} \mathrm{H}_{6}\right) ; 540$ $\mathrm{nm}\left(1700 \mathrm{M}^{-1} \mathrm{~cm}^{-1}\right)$; Anal. Calcd. for $\mathrm{C}_{30} \mathrm{H}_{37} \mathrm{IMo}_{2} \mathrm{O}_{5}: \mathrm{C}, 45.24 ; \mathrm{H}, 4.68$; Found: $\mathrm{C}$, $46.0 ; \mathrm{H}, 5.3$.

\section{Synthesis of 4.CNXyl.}

To solution of complex 4. EEt $_{2}(400 \mathrm{mg}, 0.50 \mathrm{mmol})$ in diethyl ether $(20 \mathrm{~mL})$ previously cooled to $-30 \stackrel{\circ}{\circ} \mathrm{C}$ was added a solution of $\mathrm{CN}-\left(2,6-\mathrm{Me}_{2} \mathrm{C}_{6} \mathrm{H}_{3}\right)(65 \mathrm{mg}$, $0.5 \mathrm{mmol})$ in ether $(10 \mathrm{~mL})$. A color change from blue-violet to green was observed immediately. The reaction mixture was allowed to reach room temperature with continuous stirring during 3 hours. The resulting green suspension was centrifuged and the clear solution was transferred to a Schlenk tube, concentrated and stored at $-23{ }^{\circ} \mathrm{C}$ during 24 hours. Green crystals of complex 4.CNXyl separated out, which were isolated by filtration and dried under vacuum for 2 hours. Yield: $290 \mathrm{mg}(68 \%)$. ${ }^{1} \mathrm{H}$ NMR $\left(500 \mathrm{MHz}, \mathrm{C}_{6} \mathrm{D}_{6}, 25\right.$ $\left.{ }^{\circ} \mathrm{C}\right): \delta=2.17\left(\mathrm{~s}, 6 \mathrm{H}, \mathrm{Me}_{\mathrm{Xyl}}\right), 2.19\left(\mathrm{~s}, 6 \mathrm{H}, \mathrm{Me}_{\mathrm{CNX}}\right), 2.41$ (s, 6H, Me $\left.\mathrm{Xyl}_{\mathrm{I}}\right), 2.61$ (s, $\left.6 \mathrm{H}, \mathrm{Me}_{\mathrm{OAC}}\right), 6.29\left(\mathrm{t}, 1 \mathrm{H},{ }^{3} \mathrm{~J}_{\mathrm{HH}}=7.5 \mathrm{~Hz}, p-X y l^{\prime}\right), 6.54\left(\mathrm{~d}, 2 \mathrm{H},{ }^{3} \mathrm{~J}_{\mathrm{HH}}=7.6 \mathrm{~Hz}, m\right.$ CNXyl), $6.60\left(\mathrm{~d}, 2 \mathrm{H},{ }^{3} \mathrm{~J}_{\mathrm{HH}}=7.5 \mathrm{~Hz}, m-X y l^{\prime}\right), 6.67\left(\mathrm{t}, 1 \mathrm{H},{ }^{3} \mathrm{~J}_{\mathrm{HH}}=7.6 \mathrm{~Hz}, p-\mathrm{CNXyl}\right)$, $6.80\left(\mathrm{dd},{ }^{3} \mathrm{~J}_{\mathrm{HH}}=7.6 \mathrm{~Hz},{ }^{4} \mathrm{~J}_{\mathrm{HH}}=1.0 \mathrm{~Hz}, m^{\prime}-\mathrm{C}_{6} \mathrm{H}_{3}\right), 6.97\left(\mathrm{dd}, 1 \mathrm{H},{ }^{3} \mathrm{~J}_{\mathrm{HH}}=7.6 \mathrm{~Hz}\right.$, $\left.{ }^{4} \mathrm{~J}_{\mathrm{HH}}=1.0 \mathrm{~Hz}, m-\mathrm{C}_{6} \mathrm{H}_{3}\right), 7.02(\mathrm{br} . \mathrm{s}, 3 \mathrm{H}, m-\mathrm{Xyl}$ and $p-\mathrm{Xyl}), 7.28\left(\mathrm{t}, 1 \mathrm{H},{ }^{3} \mathrm{~J}_{\mathrm{HH}}=7.6\right.$ $\left.\mathrm{Hz}, p-\mathrm{C}_{6} \mathrm{H}_{3}\right)$ ppm; ${ }^{13} \mathrm{C}$ NMR (125 MHz, $\left.\mathrm{C}_{6} \mathrm{D}_{6}, 25{ }^{\circ} \mathrm{C}\right): \delta=19.2\left(\mathrm{Me}_{\mathrm{CNXyl}}\right), 21.6$ $\left(\mathrm{Me}_{\mathrm{Xyl}}\right), 22.9\left(\mathrm{Me}_{\mathrm{XY1}}\right), 24.2\left(\mathrm{Me}_{\mathrm{OAc}}\right), 124.5\left(m^{\prime}-\mathrm{C}_{6} \mathrm{H}_{3}\right), 127.3\left(p-\mathrm{C}_{6} \mathrm{H}_{3}\right), 127.6(m-$ $\mathrm{C}_{6} \mathrm{H}_{3}$ ), 127.9-128.4 (under signal $\mathrm{C}_{6} \mathrm{D}_{6}, m-\mathrm{Xyl}, p-\mathrm{Xyl}, m-\mathrm{CNXyl}$ and ipsoCNXyl), 128.9 ( $p$-Xyl'), 129.3 (m-Xyl'), 129.7 (p-CNXyl), 134.8 (o-CNXyl), 136.4 (o-Xyl), 138.1 (o-Xyl'), 139.0 (ipso-Xyl), 142.2 (ipso-Xyl'), 144.9, $147.9\left({ }^{o}-\mathrm{C}_{6} \mathrm{H}_{3}\right.$ and $\left.o^{\prime}-\mathrm{C}_{6} \mathrm{H}_{3}\right), 174.5\left(\mathrm{Mo}-\mathrm{C}_{\mathrm{ar}}\right), 185.1\left(\mathrm{O}_{2} \mathrm{CMe}\right) \mathrm{ppm}$. Resonance due to isonitrile group not were detected; IR (CsI-Nujol): v(C-N) $2135 \mathrm{~cm}^{-1}$; UV/Vis $\left(\mathrm{C}_{6} \mathrm{H}_{6}\right) ; \lambda_{\max }$ (ع) $630 \mathrm{~nm}\left(1760 \mathrm{M}^{-1} \mathrm{~cm}^{-1}\right)$; Anal. Calcd. for $\mathrm{C}_{35} \mathrm{H}_{36} \mathrm{IMo}_{2} \mathrm{NO}_{4}$ : C, 49.26; $\mathrm{H}, 4.25$; N, 1.64; Found: C, 49.3; H, 4.1; N, 1.7 .

\section{Synthesis of $4 \cdot \mathrm{PMe}_{3}$.}

To solution of complex $4 . \mathrm{OEt}_{2}(400 \mathrm{mg}, 0.5 \mathrm{mmol})$ in diethyl ether $(15 \mathrm{~mL})$ previously cooled to $-30 \stackrel{\circ}{\circ} \mathrm{C}$ were added $0.8 \mathrm{~mL}$ of $\mathrm{PMe}_{3}(1.0 \mathrm{M}$ in toluene). $\mathrm{A}$ color change from blue-violet to deep-blue was observed quickly. The reaction mixture was allowed to reach room temperature with continuous stirring during 3 hours. Then, the reaction solution was centrifuged and the filtrate was transferred to a Schlenk tube, concentrated and stored at $-23{ }^{\circ} \mathrm{C}$ during 24 hours to give complex $\mathbf{4} \cdot \mathrm{PMe}_{3}$ as a deep-blue crystalline solid which was separated by filtration and dried under vacuum for 3 hours. Yield: $255 \mathrm{mg}$ (65\%). ${ }^{1} \mathrm{H}$ NMR $\left(500 \mathrm{MHz}, \mathrm{C}_{6} \mathrm{D}_{6}, 25^{\circ} \mathrm{C}\right): \delta=1.00\left(\mathrm{~d}, 9 \mathrm{H},{ }^{2} \mathrm{~J}_{\mathrm{HP}}=9 \mathrm{~Hz}, \mathrm{PMe}_{3}\right)$, $2.13\left(\mathrm{~s}, 6 \mathrm{H}, \mathrm{Me}_{\mathrm{xyl}}\right), 2.43\left(\mathrm{~s}, 6 \mathrm{H}, \mathrm{Me}_{\mathrm{xyl}}\right), 2.53\left(\mathrm{~s}, 6 \mathrm{H}, \mathrm{Me}_{\mathrm{OAc}}\right), 6.19\left(\mathrm{t}, 1 \mathrm{H},{ }^{3} \mathrm{~J}_{\mathrm{HH}}=\right.$ $\left.7.6 \mathrm{~Hz}, p-X y l^{\prime}\right), 6.51\left(\mathrm{~d}, 2 \mathrm{H},{ }^{3} \mathrm{~J}_{\mathrm{HH}}=7.6 \mathrm{~Hz}, m-X y l^{\prime}\right), 6.74\left(\mathrm{dd}, 1 \mathrm{H},{ }^{3} \mathrm{~J}_{\mathrm{HH}}=7.5 \mathrm{~Hz}\right.$, $\left.{ }^{4} J_{\mathrm{HH}}=1.0 \mathrm{~Hz}, m^{\prime}-\mathrm{C}_{6} \mathrm{H}_{3}\right), 7.01\left(\mathrm{dd}, 1 \mathrm{H},{ }^{3} \mathrm{~J}_{\mathrm{HH}}=7.5 \mathrm{~Hz},{ }^{4} J_{\mathrm{HH}}=1.0 \mathrm{~Hz}, m-\mathrm{C}_{6} \mathrm{H}_{3}\right)$, 7.05 (br. s, 3H, m-Xyl and $p-\mathrm{Xyl}$ ), 7.27 (t, $\left.1 \mathrm{H},{ }^{3} \mathrm{~J}_{\mathrm{HH}}=7.5 \mathrm{~Hz}, p-\mathrm{C}_{6} \mathrm{H}_{3}\right) \mathrm{ppm}$; 
${ }^{13} \mathrm{C}\left\{{ }^{1} \mathrm{H}\right\}$ NMR (125 MHz, $\left.\mathrm{C}_{6} \mathrm{D}_{6}, 25 \stackrel{\circ}{\circ} \mathrm{C}\right): \delta=13.31\left(\mathrm{~d},{ }^{1} J_{\mathrm{PC}}=27 \mathrm{~Hz}, \mathrm{PMe}\right), 21.1$ $\left.\left(\mathrm{Me}_{\mathrm{Xyl}}\right), 22.3\left(\mathrm{Me}_{\mathrm{Xyl}}\right)^{\prime}\right), 23.6\left(\mathrm{Me}_{\mathrm{OAC}}\right), 124.0\left(m^{\prime}-\mathrm{C}_{6} \mathrm{H}_{3}\right), 126.4\left(p-\mathrm{C}_{6} \mathrm{H}_{3}\right), 127.0(m-$ $\left.\mathrm{C}_{6} \mathrm{H}_{3}\right), 127.7$ (under signal $\mathrm{C}_{6} \mathrm{D}_{6}, m-\mathrm{Xyl}, p$-Xyl and $p$-Xyl'), $128.4(m-\mathrm{Xyl}), 136.0$ (o-Xyl), 138.1 (o-Xyl'), 138.9 (ipso-Xyl), 139.6 (ipso-Xyl'), 145.2, 148.8 (o- $\mathrm{C}_{6} \mathrm{H}_{3}$ and $\left.o^{\prime}-\mathrm{C}_{6} \mathrm{H}_{3}\right), 173.2$ (d, $\left.{ }^{3} \mathrm{JPC}_{\mathrm{PC}}(\operatorname{trans})=9 \mathrm{~Hz}, \mathrm{Mo}-\mathrm{C}_{\mathrm{ar}}\right), 183.7\left(\mathrm{O}_{2} \mathrm{CMe}\right) \mathrm{ppm}$; ${ }^{31} \mathrm{P}\left\{{ }^{1} \mathrm{H}\right\}$ NMR $\left(200 \mathrm{MHz}, \mathrm{C}_{6} \mathrm{D}_{6}, 25{ }^{\circ} \mathrm{C}\right): \delta=+3.73 \mathrm{ppm}$. UV/Vis $\left(\mathrm{C}_{6} \mathrm{H}_{6}\right) ; \lambda_{\max }(\varepsilon)$ $580 \mathrm{~nm}\left(1500 \mathrm{M}^{-1} \mathrm{~cm}^{-1}\right)$; Anal. Calcd. for $\mathrm{C}_{29} \mathrm{H}_{36} \mathrm{IMo}_{2} \mathrm{O}_{4} \mathrm{P}: \mathrm{C}, 43.63 ; \mathrm{H}, 4.55$; Found: $\mathrm{C}, 43.9 ; \mathrm{H}, 4.5$

\section{Synthesis of $4 \cdot \mathrm{PPr}^{i}$.}

To solution of complex $4 . \mathrm{OEt}_{2}(500 \mathrm{mg}, 0.63 \mathrm{mmol})$ in mixture of diethyl ether/pentano ( $5 \mathrm{~mL}, 5 \mathrm{~mL}$ ) previously cooled to $0{ }^{\circ} \mathrm{C}$ were added $0.3 \mathrm{~mL}$ of $\operatorname{PPr}_{3}^{i}$. The reaction mixture was allowed to reach room temperature with continuous stirring during 4 hours with the formation of a violet precipitate. The solvent was removed and the solid was washed three times with pentane (8 $\mathrm{mL}$ ). The solid was dissolved in $10 \mathrm{~mL}$ of THF and then, the solution was centrifuged and the filtrate was transferred to a Schlenk tube, concentrated and stored at $-23 \stackrel{\circ}{\circ} \mathrm{C}$ during 24 hours to form complex $4 \cdot \mathrm{PPr}_{3}^{i}$ as a violet crystalline solid which was separated by filtration and dried under vacuum for 3 hours. Yield: $380 \mathrm{mg}(70 \%)$. ${ }^{1} \mathrm{H}$ NMR $\left(500 \mathrm{MHz}, \mathrm{C}_{6} \mathrm{D}_{6}, 25 \stackrel{\circ}{\circ} \mathrm{C}\right): \delta=0.76\left(\mathrm{dd}, 18 \mathrm{H},{ }^{3} \mathrm{~J}_{\mathrm{PH}} \sim\right.$ $14 \mathrm{~Hz},{ }^{3} \mathrm{~J}_{\mathrm{HH}} \sim 7.4 \mathrm{~Hz}, \mathrm{P}(\mathrm{CHMe})_{3}$ ), 2.10 (s, 6H, Me $\mathrm{xyl}_{\mathrm{l}}$ ), 2.32 (oct, 3H, ${ }^{2} \mathrm{~J}_{\mathrm{PH}} \sim 7.4$ $\left.\mathrm{Hz},{ }^{3} \mathrm{~J}_{\mathrm{HH}} \sim 7.4 \mathrm{~Hz}, \mathrm{P}(\mathrm{CHMe})_{3}\right), 2.47\left(\mathrm{~s}, 6 \mathrm{H}, \mathrm{Me}_{\mathrm{Xy}} \mathrm{y}^{\prime}\right), 2.59$ (s, 6H, Me $\left.\mathrm{OAc}\right), 6.35(\mathrm{t}$ $\left.1 \mathrm{H},{ }^{3} J_{\mathrm{HH}}=7.5 \mathrm{~Hz}, p-X y l^{\prime}\right), 6.58\left(\mathrm{~d}, 2 \mathrm{H}, m-X y l^{\prime}\right), 6.65\left(\mathrm{~d}, 1 \mathrm{H},{ }^{3} J_{\mathrm{HH}}=7.5 \mathrm{~Hz}, m^{\prime}\right.$ $\left.\mathrm{C}_{6} \mathrm{H}_{3}\right), 6.97\left(\mathrm{~d}, 1 \mathrm{H},{ }^{3} \mathrm{~J}_{\mathrm{HH}}=7.5 \mathrm{~Hz}, m-\mathrm{C}_{6} \mathrm{H}_{3}\right), 7.09$ (br. s, $3 \mathrm{H}, m-X y l$ and $\left.p-X y l\right)$ $7.22\left(\mathrm{t}, 1 \mathrm{H},{ }^{3} \mathrm{~J}_{\mathrm{HH}}=7.5 \mathrm{~Hz}, p-\mathrm{C}_{6} \mathrm{H}_{3}\right) \mathrm{ppm} ;{ }^{13} \mathrm{C}\left\{{ }^{1} \mathrm{H}\right\} \mathrm{NMR}\left(125 \mathrm{MHz}, \mathrm{C}_{6} \mathrm{D}_{6}, 25{ }^{\circ} \mathrm{C}\right): \delta$ $=19.6\left(\mathrm{P}\left(\mathrm{CHMe}_{2}\right)_{3}\right), 21.3\left(\mathrm{Me}_{\mathrm{Xyl}}\right), 22.3\left(\mathrm{~d},{ }^{1} \mathrm{~J}_{\mathrm{PC}}=17 \mathrm{~Hz}, \mathrm{P}\left(\mathrm{CHMe}_{2}\right)_{3}\right), 22.7$ $\left(\mathrm{Me}_{\mathrm{Xyl}}\right)^{\prime}, 24.5(\mathrm{Me} \mathrm{OAc}), 124.0\left(m^{\prime}-\mathrm{C}_{6} \mathrm{H}_{3}\right), 126.3\left(p-\mathrm{C}_{6} \mathrm{H}_{3}\right), 127.2-128.2$ (under signal $\mathrm{C}_{6} \mathrm{D}_{6}, m-\mathrm{C}_{6} \mathrm{H}_{3}, p$-Xyl and $m$-Xyl), $128.8\left(m-\mathrm{Xyl}^{\prime}\right), 128.9\left(p-\mathrm{Xyl}^{\prime}\right), 136.2(o$ Xyl), 138.1 (o-Xyl'), 138.7 (ipso-Xyl), 141.0 (ipso-Xyl'), 144.8, 149.0 (o- $\mathrm{C}_{6} \mathrm{H}_{3}$ and $\left.\mathrm{o}^{\prime}-\mathrm{C}_{6} \mathrm{H}_{3}\right), 171.6\left(\mathrm{~d},{ }^{3} \mathrm{~J}_{\mathrm{PC}}(\right.$ trans $\left.)=8.6 \mathrm{~Hz}, \mathrm{Mo}-\mathrm{C}_{\mathrm{ar}}\right), 184.3\left(\mathrm{O}_{2} \mathrm{CMe}\right) \mathrm{ppm} ;{ }^{31} \mathrm{P}\left\{{ }^{1} \mathrm{H}\right\}$ NMR $\left(200 \mathrm{MHz}, \mathrm{C}_{6} \mathrm{D}_{6}, 25^{\circ} \mathrm{C}\right): \delta=+47.5 \mathrm{ppm}$. UV/Vis $\left(\mathrm{C}_{6} \mathrm{H}_{6}\right) ; \lambda_{\max }(\varepsilon) 585 \mathrm{~nm}$ $\left(1700 \mathrm{M}^{-1} \mathrm{~cm}^{-1}\right) ; \quad\left(\mathrm{CH}_{2} \mathrm{Cl}_{2}\right) ; 550 \mathrm{~nm}\left(1300 \mathrm{M}^{-1} \mathrm{~cm}^{-1}\right) ;$ Anal. Calcd. for $\mathrm{C}_{35} \mathrm{H}_{48} \mathrm{IMo}_{2} \mathrm{O}_{4} \mathrm{P}: \mathrm{C}, 47.63 ; \mathrm{H}, 5.48$; Found: $\mathrm{C}, 47.4 ; \mathrm{H}, 5.6$.

\section{Synthesis of $4 \cdot \mathrm{P}(\mathrm{OMe})_{3}$.}

To solution of complex $4 . \mathrm{OEt}_{2}(500 \mathrm{mg}, 0.63 \mathrm{mmol})$ in diethyl ether $(20 \mathrm{~mL})$ previously cooled to $0 \stackrel{\circ}{\circ}$ were added $0.3 \mathrm{~mL}$ of $\mathrm{P}(\mathrm{OMe})_{3}$. The reaction mixture was allowed to reach room temperature with continuous stirring during 4 hours to give a purple precipitate. The solvent was removed and the solid was washed three times with pentane $(15 \mathrm{~mL})$. The solid was dissolved in a mixture of $\mathrm{Et}_{2} \mathrm{O}$ THF $(20 \mathrm{~mL}, 0.5 \mathrm{~mL})$. The resulting solution was centrifuged, the filtrate was transferred to a Schlenk tube, concentrated and stored at $-23{ }^{\circ} \mathrm{C}$ during 48 hours. Purple crystals of complex 4.P(OMe $)_{3}$ were formed in the bottom of the flask which were separated by filtration and dried under vacuum for 3 hours. Yield: $400 \mathrm{mg}(75 \%) .{ }^{1} \mathrm{H}$ NMR $\left(500 \mathrm{MHz}, \mathrm{CD}_{2} \mathrm{Cl}_{2}, 0 \stackrel{\circ}{\circ} \mathrm{C}\right): \delta=2.02\left(\mathrm{~s}, 6 \mathrm{H}, \mathrm{Me}_{\text {Xyl }}\right)$, $2.18\left(\mathrm{~s}, 6 \mathrm{H}, \mathrm{Me}_{\mathrm{XY}} \mathrm{I}^{\prime}\right), 2.85\left(\mathrm{~s}, 6 \mathrm{H}, \mathrm{Me}_{\mathrm{OAc}}\right), 3.50\left(\mathrm{~d}, 9 \mathrm{H},{ }^{3} \mathrm{~J}_{\mathrm{PH}}=11 \mathrm{~Hz}, \mathrm{P}(\mathrm{OMe})_{3}\right)$ $6.75\left(\mathrm{t}, 1 \mathrm{H},{ }^{3} \mathrm{~J}_{\mathrm{HH}}=7.5 \mathrm{~Hz}, p\right.$-Xyl'), $6.78\left(\mathrm{~m}, 3 \mathrm{H}, m-\mathrm{Xyl}\right.$ and $\left.m-\mathrm{C}_{6} \mathrm{H}_{3}\right), 6.84(\mathrm{t}, 1 \mathrm{H}$ $\left.{ }^{3} \mathrm{~J}_{\mathrm{HH}}=7.5 \mathrm{~Hz}, p-\mathrm{Xyl}\right), 6.88\left(\mathrm{~d}, 1 \mathrm{H},{ }^{3} \mathrm{~J}_{\mathrm{HH}}=7.5 \mathrm{~Hz}, m^{\prime}-\mathrm{C}_{6} \mathrm{H}_{3}\right), 6.93(\mathrm{~d}, 2 \mathrm{H}, m-\mathrm{Xyl}$ and $p$-Xyl'), $7.27\left(\mathrm{t}, 1 \mathrm{H},{ }^{3} \mathrm{~J}_{\mathrm{HH}}=7.5 \mathrm{~Hz}, p-\mathrm{C}_{6} \mathrm{H}_{3}\right) \mathrm{ppm} ;{ }^{13} \mathrm{C}\left\{{ }^{1} \mathrm{H}\right\} \mathrm{NMR}(125 \mathrm{MHz}$ $\left.\mathrm{CD}_{2} \mathrm{Cl}_{2}, \mathrm{O}^{\circ} \mathrm{C}\right): \delta=20.7\left(\mathrm{Me}_{\mathrm{Xyl}}\right), 22.6\left(\mathrm{Me}_{\mathrm{Xyl}}\right), 24.4\left(\mathrm{Me}_{\mathrm{OAc}}\right), 53.2\left(\mathrm{~s}, \mathrm{P}(\mathrm{OMe})_{3}\right)$ $124.7\left(m^{\prime}-\mathrm{C}_{6} \mathrm{H}_{3}\right), 126.5\left(p-\mathrm{C}_{6} \mathrm{H}_{3}\right), 126.9\left(m-\mathrm{C}_{6} \mathrm{H}_{3}, p-X y l\right.$ and $\left.m-X y l\right), 128.9(p-$ Xyl'), 129.0 (m-Xyl'), 136.5 (o-Xyl), 138.4 (o-Xyl'), 138.9 (ipso-Xyl), 139.3 (ipsoXyl'), 145.1, $147.3\left(o-\mathrm{C}_{6} \mathrm{H}_{3}\right.$ and $\left.o^{\prime}-\mathrm{C}_{6} \mathrm{H}_{3}\right), 171.6$ (d, ${ }^{3} \mathrm{~J}_{\mathrm{PC}}($ trans $)=10.5 \mathrm{~Hz}$, Mo- $\left.\mathrm{C}_{\mathrm{ar}}\right), 185.3\left(\mathrm{O}_{2} \mathrm{CMe}\right) \mathrm{ppm} ;{ }^{31} \mathrm{P}\left\{{ }^{1} \mathrm{H}\right\}$ NMR $\left(200 \mathrm{MHz}, \mathrm{CD}_{2} \mathrm{Cl}_{2}, 0^{\circ} \mathrm{O}\right): \delta=+154$ ppm. UV/Vis $\left(\mathrm{C}_{6} \mathrm{H}_{6}\right): \lambda_{\max }(\varepsilon) 585 \mathrm{~nm}\left(1525 \mathrm{M}^{-1} \mathrm{~cm}^{-1}\right)$; Anal. Calcd. for $\mathrm{C}_{29} \mathrm{H}_{36} \mathrm{IMO}_{2} \mathrm{O}_{7} \mathrm{P}: \mathrm{C}, 41.15 ; \mathrm{H}, 4.29$; Found: $\mathrm{C}, 41.6 ; \mathrm{H}, 4.5$.

\section{Synthesis of 7 .}

To solution of complex $4 . \mathrm{OEt}_{2}$ (300 $\left.\mathrm{mg}, 0.38 \mathrm{mmol}\right)$ in THF $(5 \mathrm{~mL})$, previously cooled to $0 \stackrel{\circ}{\circ}$, was added a solution of $\mathrm{CN}_{2} \mathrm{C}_{2} \mathrm{Me}_{4}(80 \mathrm{mg}, 0.80 \mathrm{mmol})$ in THF $(3 \mathrm{~mL})$. The reaction mixture was allowed to reach room temperature with continuous stirring during 2 hours to form a magenta precipitate. The solvent was removed and the solid was washed three times with pentane $(8 \mathrm{~mL})$. Crystals suitable for X-ray analysis were obtained by cooling at $5 \stackrel{\circ}{\circ} \mathrm{C}$ of a saturated solution of complex 7 in a mixture of dichloromethane-toluene. Magenta crystals separated out, which were collected by filtration and dried under vacuum for 2 hours. Yield: $220 \mathrm{mg}(60 \%) .{ }^{1} \mathrm{H}$ RMN (500 MHz, $\mathrm{CD}_{2} \mathrm{Cl}_{2}, 25$ $\left.{ }^{\circ} \mathrm{C}\right): \delta=1.90\left(\mathrm{~s}, 12 \mathrm{H}, \operatorname{Me}_{\mathrm{NHC}(\mathrm{B})}\right), 2.10\left(\mathrm{~s}, 12 \mathrm{H}, \mathrm{Me}_{\mathrm{Xyl}}\right), 2.52\left(\mathrm{~s}, 12 \mathrm{H}, \mathrm{Me}_{\mathrm{NHC}(\mathrm{A})}\right)$, 2.80 (s, 6H, Me $\left.\mathrm{OAc}_{\mathrm{C}}\right), 6.67\left(\mathrm{~m}, 4 \mathrm{H}, m-\mathrm{C}_{6} \mathrm{H}_{3}, p-\mathrm{Xyl}\right), 6.74(\mathrm{~m}, 4 \mathrm{H}, m-\mathrm{Xyl}), 7.14(\mathrm{t}$ $\left.1 \mathrm{H},{ }^{3} \mathrm{~J}_{\mathrm{HH}}=7.6 \mathrm{~Hz}, p-\mathrm{C}_{6} \mathrm{H}_{3}\right) \mathrm{ppm} ;{ }^{13} \mathrm{C}\left\{{ }^{1} \mathrm{H}\right\} \operatorname{NMR}\left(125 \mathrm{MHz}, \mathrm{CD}_{2} \mathrm{Cl}_{2}, 25 \stackrel{\circ}{\circ} \mathrm{C}\right): \delta=9.7$
$\left(\mathrm{Me}_{\mathrm{NHC}(\mathrm{B})}\right), 22.3\left(\mathrm{Me}_{\mathrm{Xyl}}\right), 25.1$ (Me $\left.\mathrm{OAC}\right), 34.4\left(\mathrm{Me}_{\mathrm{NHC}(\mathrm{A})}\right), 126.2\left(p-\mathrm{C}_{6} \mathrm{H}_{3}\right), 126.3(m-$ $\left.\mathrm{C}_{6} \mathrm{H}_{3}\right), 127.9\left(\mathrm{C}\left\{\mathrm{N}\left(\mathrm{Me}_{\mathrm{A}}\right) \mathrm{CMe}_{\mathrm{B}}\right\}_{2}\right), 128.1(p-\mathrm{Xyl}), 128.2(m-\mathrm{Xyl}), 138.6(o-\mathrm{Xyl})$, 141.3 (ipso-Xyl), $148.3\left(o-\mathrm{C}_{6} \mathrm{H}_{3}\right), 173.6\left(\mathrm{Mo}-\mathrm{C}_{\mathrm{ar}}\right), 184.6\left(C\left\{\mathrm{~N}\left(\mathrm{Me}_{\mathrm{A}}\right) \mathrm{CMe}_{\mathrm{B}}\right\}_{2}\right)$, $185.7\left(\mathrm{O}_{2} \mathrm{CMe}\right)$. UV/Vis $\left(\mathrm{CH}_{2} \mathrm{Cl}_{2}\right): \lambda_{\max }(\varepsilon) 555 \mathrm{~nm}\left(1575 \mathrm{M}^{-1} \mathrm{~cm}^{-1}\right)$; Anal. Calcd. For $\mathrm{C}_{40} \mathrm{H}_{51} \mathrm{IMo}_{2} \mathrm{~N}_{4} \mathrm{O}_{4}$ : C, 49.50; $\mathrm{H}, 5.30 ; \mathrm{N}, 5.77$; Found: C, 49.1; H, 5.6; N, 5.1.

\section{Computational Details}

All the calculations have been obtained at the density functional theory (DFT) level using the B3LYP exchange-correlation functional with the help of the Gaussian 09 suite of programs. ${ }^{[28]}$ Optimized molecular geometries have been done with the 6-311G(d,p) basis set for all atoms except for Mo for which relativistic Stuttgart/Dresden pseudopotentials and the SDD basis set was used. The analysis of the vibrational frequencies has been done within the harmonic approximation. The potential energy curves for the dissociation of the benzene ring from $\left[\mathrm{Mo}_{2}(\mathrm{H})\left(\mathrm{O}_{2} \mathrm{CMe}\right)_{3}\left(\eta^{1}-\mathrm{C}_{6} \mathrm{H}_{6}\right)\right]$ as well as the BSSE-corrected interaction energies were calculated performing single point calculations on the optimized geometries with the TZVPalls2 triple- $\varsigma$ basis set ${ }^{[29]}$ for Mo. A topological analysis of the electron density has been carried out with the AIMAll software. ${ }^{[30]}$

\section{Acknowledgements}

Financial support (FEDER contribution and Subprogramas Juan de la Cierva) from the Spanish Ministry of Science and Innovation (Projects CTQ2010-15833, CTQ2011-23862-C02-01 and Consolider-Ingenio 2010 CSD2007-00006), the Generalitat de Catalunya (Project 2009SGR-1459), and the Junta de Andalucía (Grant FQM-119 and Project P09-FQM-5117) is gratefully acknowledged. M. C. and I. M. thank the Spanish Ministry of Education (AP-4193) and Consolider-Ingenio 2010 CSD200700006).

\section{Keywords: Quadruple bond • molybdenum • terphenyl ligand •} Lewis bases $\cdot$ density functional calculation

[1] a) R. F. W. Bader, J. Hernández-Trujillo, F. Cortés-Guzmán, J. Comp. Chem. 2007, 28, 4-14; b) G. Frenking, A. Krapp, J. Comp. Chem. 2007, 28, 15-24; c) S. Shaik, J. Comp. Chem. 2007, 28, 51-61.

[2] H. S. Rzepa, Nat. Chem. 2009, 1, 510-512.

[3] See for instance: a) R. Martin, S. L. Buchwald, Acc. Chem. Res. 2008, 41, 1461-1473; b) D. W. Stephan, G. Erker, Angew. Chem. Int. Ed. 2010, 49, 46-76.

[4] a) R. Wolf, C. Ni, T. Nguyen, M. Brynda, G. J. Long, A. D. Sutton, R. C. Fischer, J. C. Fettinger, M. Hellman, L. Pu, P. P. Power, Inorg. Chem. 2007, 46, 11277-11290; b) T. Nguyen, A. D. Sutton, M. Brynda, J. C. Fettinger, G. J. Long, P. P. Power, Science 2005, 310, 844-847.

[5] a) M. Brynda, L. Gagliardi, P.-O. Widmark, P. P. Power, B. O. Roos, Angew. Chem. Int. Ed. 2006, 45, 3804-3807; b) T. Nguyen, W. A. Merrill, C. Ni, H. Lei, J. C. Fettinger, B. D. Ellis, G. J. Long, M. Brynda, P. P. Power, Angew. Chem. Int. Ed. 2008, 47, 9115-9117; c) G. La Macchia, L. Gagliardi, P. P. Power, M. Brynda, J. Am. Chem. Soc. 2008, 130, 51045114.

[6] a) M. Carrasco, I. Mendoza, M. Faust, J. López-Serrano, R. Peloso, A Rodríguez, E. Álvarez, C. Maya, P. P. Power, Ernesto Carmona, J. Am. Chem. Soc. 2014, 136, 9173-9180; b) M. Carrasco, M. Faust, R. Peloso, A. Rodríguez, J. López-Serrano, E. Álvarez, C. Maya, P. P. Power, E. Carmona, Chem. Commun. 2012, 48, 3954-3956.

[7] S. Alvarez, Dalton Trans. 2013, 42, 8617-8636.

[8] P. S. Pregosin, NMR in Organometallic Chemistry, Wiley-VCH, Weinheim, 2012.

[9] a) G. S. Girolami, V. V. Mainz, R. A. Andersen, J. Am. Chem. Soc. 1982, 104, 2041-2042; b) G. S. Girolami, V. V. Mainz, R. A. Andersen, J. Am. Chem. Soc. 1981, 103, 3953-3955. 
[10] F. A. Cotton, L. M. Daniels, E. A. Hillard, C. A. Murillo, Inorg. Chem 2002, 41, 2466-2470.

[11] a) P. M. Treichel, Avd. Organomet. Chem. 1973, 11, 21-86; b) Y. Yamamoto, Coord. Chem. Rev. 1980, 32, 193-233.

[12] S. D. Stults, R. A. Andersen, A. Zalkin, Organometallics 1990, 9, 115122.

[13] M. del Mar Conejo, J. S. Parry, E. Carmona, M. Schultz, J. G. Brennann, S. M. Beshouri, R. A. Andersen, R. D. Rogers, S. Coles, M. Hursthouse Chem. Eur. J. 1999, 5, 3000-3009.

[14] F. A. Cotton, K. J. Wiesinger, Inorg. Chem. 1992, 31, 920-925.

[15] M. D. Hopkins, W. P. Schaefer, M. J. Bronikowski, W. H. Woodruff, V. M. Miskowski, R. F. Dallinger, H. B. Gray, J. Am. Chem. Soc. 1987, 109 408-416.

[16] a) D. Lazdins, M. Karplus, J. Am. Chem. Soc. 1965, 87, 920-921; b) F. A. Cotton, Z. C. Mester, T. R. Webb, Acta Cryst. 1974, B30, 2768-2770.

[17] D. G. Gusev, Organometallics 2009, 28, 6458-6461.

[18] T. G. Appleton, M. A. Bennett, Inorg. Chem. 1978, 17, 738-747.

[19] G. Seidel, B. Gabor, R. Goddard, B. Heggen, W. Thiel, A. Fürstner, Angew. Chem. Int. Ed. 2014, 53, 879-882.

[20] a) L. Perrin, E. Clot, O. Eisenstein, J. Loch, R. H. Crabtree, Inorg. Chem. 2001, 40, 5806-5811; b) D. G. Gusev, Organometallics 2009, 28, 763-770.

[21] J. L. Atwood, W. E. Hunter, R. D. Rogers, E. Carmona-Guzman, G. Wilkinson, J. Chem. Soc., Dalton trans, 1979, 10, 1519-1523.

[22] a) F. Carre, R. J. P. Corriu, C. Guerin, B. J. L. Henner, B. Kolani, W. W C. Wong Chi Man, J. Organomet. Chem. 1987, 328, 15-34; b) P. W. Codding, K. A. Kerr, A. Oudeman, T. S. Sorensen, J. Organomet. Chem. 1982, 232, 193-199.

[23] A. B. Brignole, F. A. Cotton, Z. Dori, Z. Dori, Z. Dori, G. Wilkinson, Rhenium and Molybdenum Compounds Containing Quadruple Bonds in Inorganic Syntheses, Vol. 13 (ed F. A. Cotton), John Wiley \& Sons, Inc., Hoboken, NJ, USA, 2007.

[24] F. A. Cotton, J. G. Norman Jr., J. Coord. Chem. 1971, 1, 161-172.

[25] a) P. P. Power, Main Group Chem. 1998, 2, 275-283; b) E. Rivard, P. P. Power, Inorg. Chem. 2007, 46, 10047-10064.

[26] B. Schiemenz, P P. P.ower, Organometallics 1996, 15, 958-964.

[27] M. Anioł, K. Szymańska, A. Żołnierczyk, Tetrahedron 2008, 64, 9544-9547.
[28] M. J. Frisch, et al., Gaussian09 (B.1), Gaussian, Inc., Wallingford, CT, 2010

[29] A. Schäefer, C. Huber, R. Ahlrichs, J. Chem. Phys. 1994, 100, 5829-5835.

[30] T. Keith, AIMAll (10.12.08), 2010.
Received: ((will be filled in by the editorial staff)) Revised: ((will be filled in by the editorial staff)) Published online: ((will be filled in by the editorial staff)) 
Entry for the Table of Contents (Please choose one layout only)

Layout 1:

\section{FULL PAPER}

Text for Table of Contents, max. 450 characters.

Layout 2:

\section{FULL PAPER}

((The TOC Graphic should not exceed the size of this area))
Subject Heading

Author(s), Corresponding Author(s)*
Title
Reactivitiy of compounds $\mathrm{Mo}_{2}\left(\mathrm{Ar}^{\prime}\right)(\mathrm{I})\left(\mathrm{O}_{2} \mathrm{CR}\right)_{2}\left(\mathrm{OEt}_{2}\right)$ with different Lewis bases

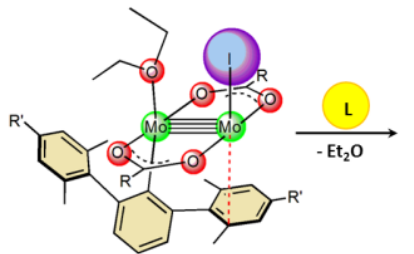

$R^{\prime}=H, R=M e, 4 \cdot L$

$R^{\prime}=M e, R=M e, 5 \cdot L$

$\mathrm{R}^{\prime}=\mathrm{H}, \mathrm{R}=\mathrm{CF}_{3}, \mathbf{6} \cdot \mathrm{L}$

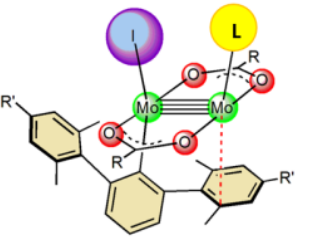

$\mathrm{L}=\mathrm{PMe}_{3}, \mathrm{PPr}_{3}^{\prime}, \mathrm{P}(\mathrm{OMe})_{3}, \mathrm{CNXYI}$

Experimental and computational studies on a series $\mathrm{Mo}_{2}\left(\mathrm{Ar}^{\prime}\right)(\mathrm{I})\left(\mathrm{O}_{2} \mathrm{CR}\right)_{2}(\mathrm{~L})$ complexes that possess a Mo-Mo quadruple bond reveal the existence of a weak $\mathrm{Mo}-\mathrm{C}_{\text {arene }}$ interaction with a flanking aryl ring of the terphenyl ligand that counterbalances the electronic unsaturation of the low-coordinate molybdenum atom. The interaction is feeble in terms of electron density sharing (the Mo- $\mathrm{C}_{\text {arene }}$ bond is ca. $15-20 \%$ longer than the $\sigma$ Mo- $\mathrm{C}_{\text {aryl }}$ bond) but denotes a two-electron donor role of the flanking aryl ring.

Mo-Mo Quadruple Bond

Mario Carrasco, ${ }^{[a]}$ Irene Mendoza, ${ }^{[a]}$ Eleuterio Álvarez, ${ }^{[a]}$ Abdessamad Grirrane ${ }^{[a]}$ Celia Maya, ${ }^{[a]}$ Riccardo Peloso, ${ }^{[a]}$ Amor Rodríguez, ${ }^{[a]}$ Andrés Falceto, ${ }^{[b]}$ Santiago Álvarez, ${ }^{*[b]}$ and Ernesto Carmona ${ }^{\star[a]}$

$\mathbf{a}-\mathbf{\square}$

Experimental and Computational Studies of the Molybdenum-Flanking Arene Interaction in Quadruply Bonded Dimolybdenum Complexes with Terphenyl Ligands 